\title{
Exploring Roman and early-medieval habitation of the Rhine-Meuse delta: modelling large-scale demographic changes and corresponding land-use impact
}

\author{
Rowin J. van Lanen ${ }^{1,2, *}$, Maurice T.M. de Kleijn ${ }^{3}$, Marjolein T.I.J. Gouw-Bouman ${ }^{1}$ \\ \& Harm Jan Pierik ${ }^{1}$
}

1 Faculty of Geosciences, Utrecht University, P.0. Box 80.115, 3508 TC Utrecht, the Netherlands

2 Cultural Heritage Agency of the Netherlands, P.0. Box 1600, 3800 BP, Amersfoort, the Netherlands

3 SPINlab - Spatial Information Laboratory, De Boelelaan 1105, 1081 HV Amsterdam, the Netherlands

* Corresponding author. Email: r.van.lanen@outlook.com

Manuscript received: 12 0ctober 2017, accepted: 1 June 2018

\section{Abstract}

In this study we apply an evidence-based approach to model population-size fluctuations and their corresponding impact on land use during the Roman and early-medieval periods in the Rhine-Meuse delta in the present-day Netherlands. Past-population numbers are reconstructed based on Roman and early-medieval settlement patterns. Corresponding impacts of these demographic fluctuations on potential land use are calculated by integrating the newly developed demographic overviews with archaeological and geoscientific data using a new land-use model termed 'Past LandUse Scanner' (PLUS). The primary aims are to reconstruct first-millennium palaeodemographics and to explore the potential of simulation modelling for testing the feasibility of archaeological hypotheses regarding past land use. Results show that in the study area the first millennium AD was characterised by two periods during which major population growth occurred: the middle-Roman period (AD 70-270) and early-medieval period C (AD 725-950). A major demographic decline of 78-85\% occurred during the late-Roman period (AD 270-450), after which first-millennium population numbers never again reached middle-Roman period levels. The modelling outcomes demonstrate that the impact of population fluctuations (growth vs decline) on the limits of the natural landscape during the first millennium in general was low. During these thousand years, the natural landscape almost without exception (only scenario D deviates) provided sufficient options for arable farming, meadows and pastures and was not a limiting factor for population growth. These results underline the added value of simulation modelling for testing the feasibility of archaeological hypotheses and analysing human-landscape interactions in the past.

Keywords: archaeology, Early Middle Ages, historical land use, palaeodemography, Roman period, simulation modelling

\section{Introduction}

The main goal of this study is to explore the added value of simulation modelling for testing archaeological hypotheses by using a two-step approach. The first step is to quantify Roman and early-medieval population numbers in the Rhine-Meuse delta. The second is to determine the general impact of palaeodemographic fluctuations on past land use and whether or not these exceeded the limits of the natural landscape in this area. This was done by testing the feasibility of three archaeological hypotheses, two of which have dominated the archaeological debate during the last decade (Table 1, hypotheses 2 and 3).
Although the term (palaeo)demography traditionally may encompass a multitude of demographic elements (e.g. population size, composition, age or origin), (palaeo)demography in this study is defined solely as the size of the population during a specific archaeological period.

The essential role of palaeodemographic studies for archaeological-interpretative frameworks has already been put forward in several archaeological studies (e.g. Hassan, 1981; Theuws, 1988; Shennan, 1998; Chamberlain, 2006; De Moor, 2016; Verhagen et al., 2016a). Chamberlain (2006, p. 177) stated that demographic studies might contribute significantly to archaeology since they can: (1) help to place constraints on 
Table 1. Archaeological hypotheses (including main references stating these claims) regarding Roman and early-medieval demography and land use in the study area.

\begin{tabular}{|c|c|c|c|}
\hline \multicolumn{2}{|l|}{ Hypothesis 1} & \multicolumn{2}{|r|}{ Hypothesis 2} \\
\hline \multirow{5}{*}{$\begin{array}{l}\text { First millennium AD } \\
(12 \mathrm{BC}-\mathrm{AD} 1050)\end{array}$} & \multirow{5}{*}{$\begin{array}{l}\text { Inhabitants of the study area were } \\
\text { self-sufficient in terms of food supply, i.e. the } \\
\text { landscape provided sufficient local options for } \\
\text { arable farming, meadows and pastures. }\end{array}$} & & $\begin{array}{l}\text { The demand of Roman military presence } \\
\text { exceeded the amount of food supply the } \\
\text { landscape could provide. }\end{array}$ \\
\hline & & $\begin{array}{l}\text { Roman period } \\
\qquad(12 \mathrm{BC}-\mathrm{AD} 450)\end{array}$ & $\begin{array}{l}\text { Sources: Groenman-van Waateringe, 1983; } \\
\text { Kooistra, 1996; Kooistra et al., 2013; } \\
\text { Van Dinter et al., 2014; NOaA 2.0, cf. } \\
\text { Groenewoudt et al., } 2017 .\end{array}$ \\
\hline & & & Hypothesis 3 \\
\hline & & $\begin{array}{l}\text { Early Middle Ages } \\
\text { (AD 450-1050) }\end{array}$ & $\begin{array}{l}\text { The development of Dorestad had major } \\
\text { consequences in terms of the amount of } \\
\text { food supply the landscape could provide. }\end{array}$ \\
\hline & & & $\begin{array}{l}\text { Sources: Van Es \& Hessing, 1994; NOaA } \\
\text { 2.0, cf. Groenewoudt et al., } 2017 .\end{array}$ \\
\hline
\end{tabular}

the kinds of populations that could have existed in the past; and (2) assist in evaluating the nature of the demographic processes that contributed to observed patterning in the archaeological record. Since the archaeological record per definition is fragmented and incomplete due to depositional and post-depositional processes (Schiffer, 1976, 1987), palaeodemographic studies can provide valuable additional spatiotemporal frameworks for interpreting the archaeological record. Moreover, recent developments in, among others, digital infrastructures and techniques, such as Geographical Information Systems (GIS), for the first time provide digital data and tools with which to reconstruct and quantify large-scale population sizes and to determine the impact of population fluctuations on past land use.

The study area is the fluvial-dominated part of the RhineMeuse delta, located in the heart of the present-day Netherlands (Fig. 1). This region was densely populated, especially from the Bronze Age onwards, because of its fertile substrates (2000800 BC; Louwe Kooijmans, 1974; Arnoldussen, 2008). Its high level of (long-distance) connectivity to central Europe and to the British Isles provided abundant long-distance transport options (e.g. Cunliffe, 2004; McCormick, 2007). During the first millennium $\mathrm{AD}$ the delta was characterised by large-scale cultural and natural changes (e.g. Henderikx, 1983; Willems, 1986; Van Es and Verwers, 2010; Jansma et al., 2014; Pierik \& Van Lanen, 2017; Van Dinter et al., 2017; Van Lanen \& Pierik, 2017). As was the case in many other parts of Europe, Roman occupation during the first centuries of this millennium generated an unprecedented (as yet unquantified) demographic and economic growth. The collapse of the Roman frontier (limes) around $\mathrm{AD} 270$, however, led to large-scale depopulation, economic decline and political instability (e.g. Alföldi, 1967; Willems, 1986; Cheyette, 2008; Van Dinter, 2013; Heeren, 2015). This decline continued for centuries and only started to reverse during the 6th century $\mathrm{AD}$, when also long-distance transport by water increased again (Van Es \& Verwers, 2010). By the 7th century the major rivers in the Netherlands had regained much of their transport-geographical importance, heralding a new period of economic and demographic growth. The impact of economic and demographic fluctuations on the natural (abiotic) landscape is unclear for the first millennium $A D$, and research quantifying these changes and their impact on land use is rare.

Two recent studies have stressed the need for more research focusing on past human-landscape interactions in the presentday Netherlands (including quantitative population-size and land-use reconstructions; cf. Pierik \& Van Lanen, 2017; Van Lanen \& Pierik, 2017). These studies, focused on reconstructing the impact of natural setting and forcing on settlement patterns and route networks in the Rhine-Meuse delta during the first millennium $\mathrm{AD}$, demonstrate the complexity of the interactions and interrelationships between large-scale cultural and natural factors such as settlement dynamics, route networks, floods and avulsions. The findings of these studies show the necessity of integrating population-size and land-use reconstructions when studying human-landscape interactions and connectivity patterns during this time interval (cf. Section 2).

\section{Theoretical background: palaeodemographics, land use and connectivity patterns}

Demographic reconstructions pertaining to the Rhine-Meuse delta have mainly focused on (parts of) the early-Roman and middle-Roman periods (12 BC-AD 270). In older studies by Bloemers (1978) and Willems (1986) and more recent studies by Vossen (2003), Vos (2009) and Verhagen et al. (2016a), Roman population estimates for the Dutch limes zone are 

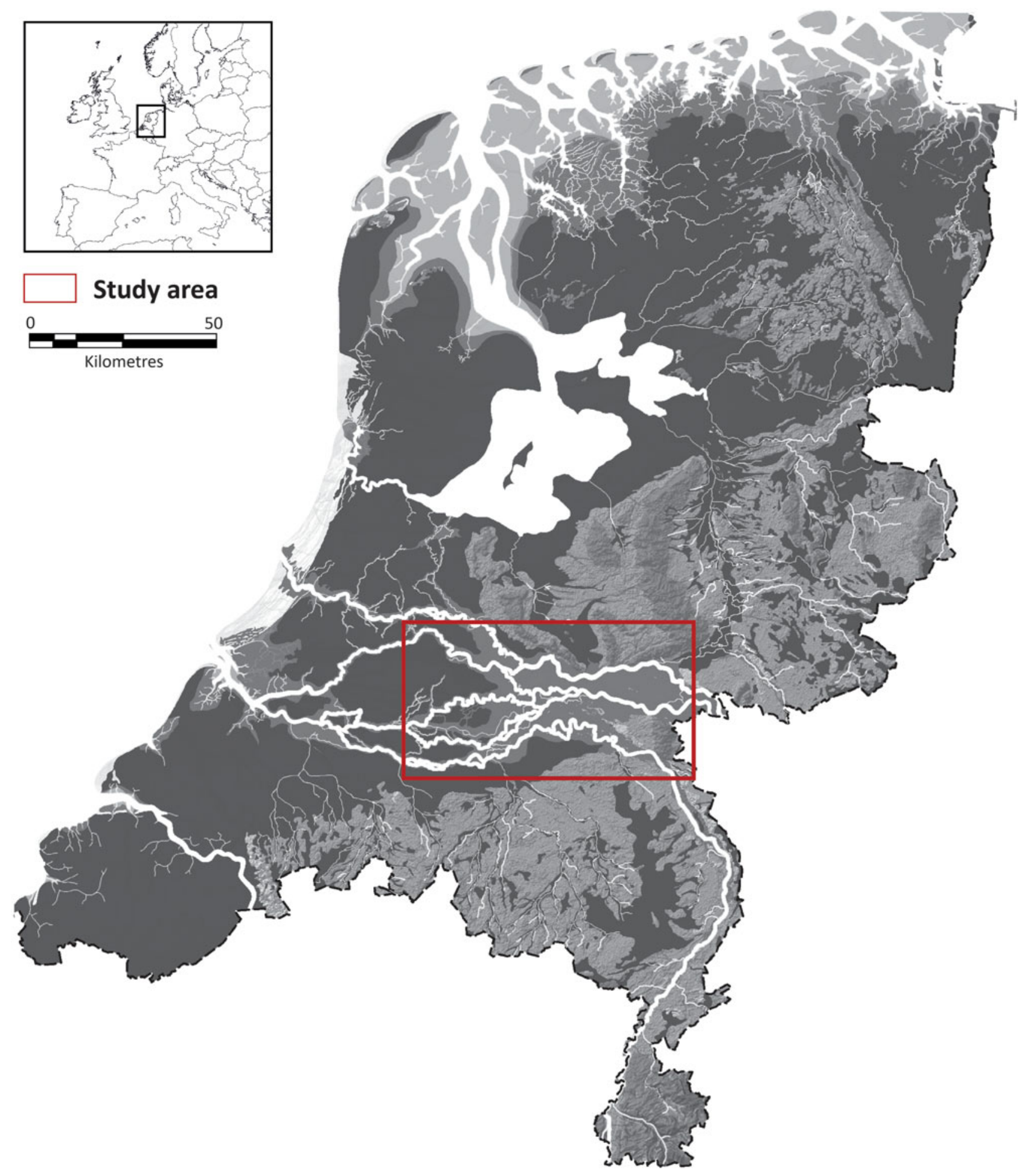

.

Fig. 1. The location of the research area (red) in the Netherlands. This location is overlain on the palaeogeographical situation of c. AD 100, adapted from Vos \& De Vries (2013).

calculated based on a variety of methods. Mostly two types of models have been applied: (1) the so-called recruitment model $(\mathrm{RM})$, which determines palaeodemographics based on Roman military-requirement numbers known from historical sources (Bloemers, 1978; Willems, 1986); and (2) the settlement-density model (SDM), which calculates palaeodemographics based on settlement numbers, the average number of houses per settlement, and average household size (Bloemers, 1978; Willems, 1986; Vossen, 2003; Vos, 2009; Dijkstra, 2011). Recently, it has been suggested that many of these estimates are based on an insufficient understanding and incorporation of processes such as natural-population growth, migration, military recruitment, 
and effects of low-level urbanisation in many of these models (Verhagen et al., 2016a). Against this background we apply a newly developed SDM to the Rhine-Meuse delta because: (1) the majority of the first-millennium population must have lived in rural settlements; (2) high-quality settlement data are available for this area, allowing an evidence-based approach when reconstructing population dynamics; (3) it is impossible to verify the reliability of historical sources mentioning Roman armyrecruitment numbers; (4) this model allows calculation of the relative contribution of low-level urbanisation through the analysis of individual large settlements ( $>5 \mathrm{ha}$ ).

The dynamic relationship between people and their environment is reflected, among others, in changing land use. Since the 1970s, archaeologists have been developing (computer) models in order to study the complex interplay between demographic fluctuations and land-use changes. Especially in landscape archaeology, simulation models designed for this specific purpose have gained increasing attention (Lake, 2014). However, it is commonly recognised that many archaeological simulation models underrepresent processes of social complexity and naturallandscape dynamics. Although a growing number of studies recognise the necessity of integrating complex cultural and sociological factors in archaeological (simulation) modelling (e.g. Van der Leeuw \& McGlade, 1997; Goodchild \& Witcher, 2010; Whitley et al., 2010), this remains one of the major challenges (Lake, 2014). A simulation-modelling framework introduced by De Kleijn et al. (in press) was designed to incorporate cultural factors in order to model the competition between different types of land use. We used this modelled framework in order to test the feasibility of archaeological hypotheses. The presented model explicitly does not reconstruct first-millennium land use, but only tests the capacity of the natural landscape to cope with demographic fluctuations. By adapting the PLUS model to specific variables hypothetically reflecting Roman and early-medieval conditions, we were able to simulate the probable impact of palaeodemographic fluctuations on the contemporary landscape. Data on first-millennium land use, such as the average amount of calories per delta inhabitant/soldier and average yield per land unit, were derived from studies focused on Roman land use in the western Netherlands (Kooistra et. al., 2013; Van Dinter et al., 2014).

Recent research of Roman and early-medieval settlement patterns and route networks in the Rhine-Meuse delta has demonstrated multi-scale variability in cultural and natural processes, among others showing that settlements were spatially dynamic and clearly influenced by natural forcings such as flooding, whereas route zones in this area were characterised by a high level of persistence (Van Lanen \& Pierik, 2017). The implication is that throughout the first millennium, processes of persistence and change coincided. Based on the findings it was concluded that cultural processes such as the development of settlement patterns and route networks are part of larger complex networks of cultural manifestations that are closely intertwined and con- tinuously influence each other. Van Lanen \& Pierik (2017) defined this complex network as 'connectivity patterns', which they regard as the dynamic spatial and social interrelations of, and interactions between, the following landscape-influencing factors: settlement patterns, land use, demography, route networks, long-distance transport routes and physical landscapeformation processes. Within connectivity patterns, changes in one factor (e.g. demography or land use), can lead to farreaching ripple effects within the system. They concluded that these combined connectivity-pattern factors (CPFs) are key for studying large-scale human-landscape interactions. Population size and land use are the next two CPFs which are analysed in the current study.

\section{Material}

In order to calculate palaeodemographics and its corresponding impact on land use we used recently developed archaeological datasets, geomorphological reconstructions and GIS-simulation modelling.

\subsection{Archaeology}

Rural population numbers were reconstructed based on Roman and early-medieval settlement data derived from the Archaeological Information System of the Netherlands (ARCHIS). ARCHIS contains a continuously updated supraregional overview of known archaeological finds (Roorda \& Wiemer, 1992; Wiemer, 2002). We expanded this dataset with detailed published (meta)data from regional overview studies (Bechert \& Willems, 1995; Verwers, 1998). Data on Roman military structures were derived from the LGL World Heritage database (2010). Specifics on larger settlements were collected through the Electronic Archiving System (EASY) and from published overview studies (for a full overview of used publications see Appendix A (available online at https://doi.org/10.1017/njg.2018.3) and the references at the end of this paper). EASY is an online archiving system for archaeological excavation data, such as figures, GIS files, photos and research reports. Chronological diversification within the model was based on the Archaeological Basic Register (ABR). On archaeological and historical grounds the ABR differentiates three Roman and four early-medieval periods (Table 2). These periods roughly cover, on average, 100-200 years. We chose these short time intervals to calculate population-size fluctuations using the highest possible chronological resolution. Consequently, roughly dated settlements, i.e. dating to only the Roman or early-medieval period as a whole, were excluded from the analysis since their chronological resolution is too low to yield reliable population-size fluctuations. Continuously inhabited settlements are extremely rare in the study area but were individually included in the dataset when classified as such in 
Table 2. Periods and subperiods as specified by the Archaeological Basic Register (ABR).

\begin{tabular}{|c|c|c|c|}
\hline Archaeological Period & Subperiod & Abbreviation & Age \\
\hline \multirow{3}{*}{ Roman period (RP) } & early-Roman period & ERP & $12 \mathrm{BC}-\mathrm{AD} 70$ \\
\hline & middle-Roman period & MRP & AD 70-270 \\
\hline & late-Roman period & LRP & AD 270-450 \\
\hline \multirow{4}{*}{ Early Middle Ages (EMP) } & early-medieval period A & EMPA & AD 450-525 \\
\hline & early-medieval period B & EMPB & AD 525-725 \\
\hline & early-medieval period C & EMPC & AD 725-900 \\
\hline & early-medieval period D & EMPD & AD $900-1050$ \\
\hline
\end{tabular}

archaeological publications (overview studies and excavation reports).

\subsection{Palaeographical reconstructions}

Input criteria for land-use suitability were derived from newly developed, high-resolution geomorphological reconstructions for $\mathrm{AD}$ 100, 500 and 900, and from a palaeo-digital elevation model (palaeoDEM) compiled by Pierik et al. (2017). Based on these datasets also the lithology of the study area was reconstructed (Section 4.2).

Geomorphological reconstructions The geomorphological maps for AD 100, 500 and 900 developed by Pierik et al. (2017) show landscape elements from which differences in land-use suitability in the delta were deduced for each of these time slices (Fig. 2). These maps in unprecedented detail outline the spatial extent, distribution and orientation of alluvial ridges, including channel belts, natural levees, crevasse splays and floodbasins. These geomorphological elements were mapped using lithological and geomorphological criteria following the methodology developed by Berendsen \& Stouthamer (2000), Van Dinter (2013), Vos (2015) and Pierik et al. (2016). Lithological information was obtained from an extensive borehole database maintained by Utrecht University, and modern elevation data were derived from lidar images (Berendsen \& Volleberg, 2007). The dating of the mapped elements is based on ${ }^{14} \mathrm{C}$ dates, archaeology and relative dating (Berendsen \& Stouthamer, 2000; Cohen et al., 2012). The geomorphological reconstructions expand on existing regional studies (e.g. Willems, 1986; Van Dinter, 2013; Van Dinter et al., 2017). They have a higher resolution than previous delta-wide and national reconstructions, are more accurate and show more landscape elements.

Palaeo Digital-elevation Model (palaeoDEM) Within the mapped geomorphological units, elevation influences terrain wetness and thus land-use potential. Pierik et al. (2017) developed a palaeo-surface reconstruction distinguishing higher and lower areas in the delta around AD 100 using a $100 \times 100 \mathrm{~m}$ gridcell resolution (Fig. 3). Higher areas in this dataset were assigned a higher suitability than the lower areas (Appendix B, available online at https://doi.org/10.1017/njg.2018.3). This palaeo-surface topography (palaeoDEM) was compiled by interpolating the vertical position of the top of the typical naturallevee lithology dating to the Roman period (e.g. loams, sandy clays) derived from the lithological-borehole data (Pierik et al., 2017). This dataset has been corrected for younger clay sedimentation on abandoned levees and normalised for the deltaplain gradient (around $+8 \mathrm{~m}$ OD in the east to around $-1 \mathrm{~m}$ OD in the west). This normalisation was performed by subtracting groundwater-level reconstructions dated to 2000 years BP (Cohen, 2005; Koster et al., 2016) from the palaeo-surface reconstruction. The resulting map shows the elevation of the landscape relative to the reconstructed past groundwater level in the delta, and therefore allows different regions within the delta to be compared to each other. Actively forming levees, dike-breach deposits of post-Roman active rivers, and embanked floodplains were omitted from the palaeoDEM, because they hamper the reconstruction of past landscape elevation and only make up a very small percentage of the total surface area.

\subsection{Past land-use scanner (PLUS)}

The PLUS modelling framework integrates cultural and natural factors in order to simulate past land use on a regional level and was developed for the western Netherlands (De Kleijn et al., in press). This approach has its roots in economic theory and is derived from a contemporary land-use scanner which originally was developed in order to predict land-use development in the near future based on policy maps (Hilferink \& Rietveld, 1999; Koomen \& Borsboom-van Beurden, 2011). The PLUS model simulates the allocation of land use by mimicking the spatial competition between different land-use types, combining the estimated regional demand with the suitability for various landuse types. For each land-use type the suitability is determined based on a combination of physical-landscape characteristics, economic-distance relations, political factors and sociological aspects. This suitability is confronted with a demand for land use which can be derived from, for instance, palaeodemographic reconstructions (cf. this study). Combining the two, the PLUS allocates the required land to the most suitable location (De Kleijn et al., in press). 

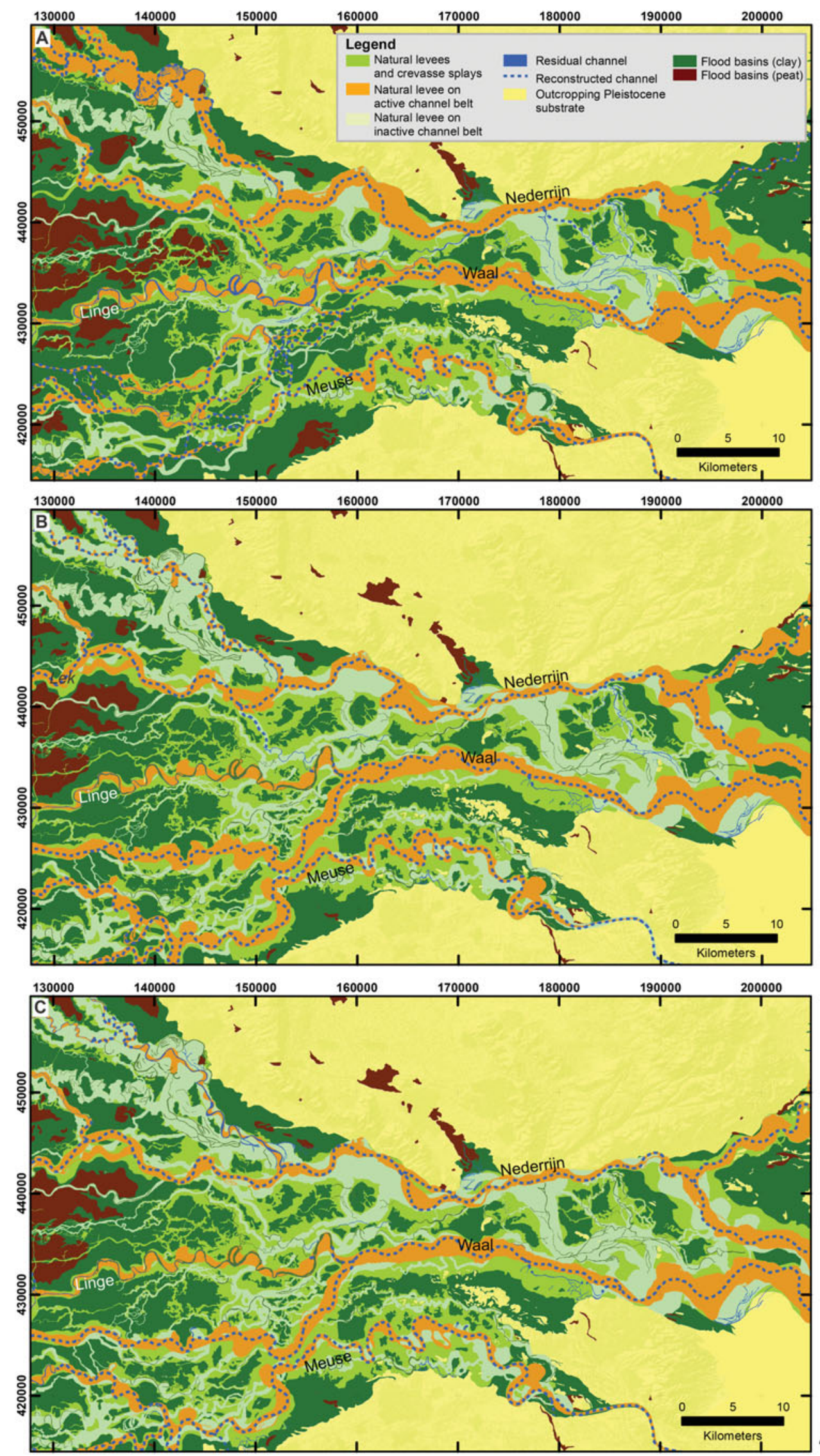

Fig. 2. Geomorphological reconstructions of the Rhine-Meuse delta around AD 100, 500 and 900 (adapted from Pierik et al., 2017). 

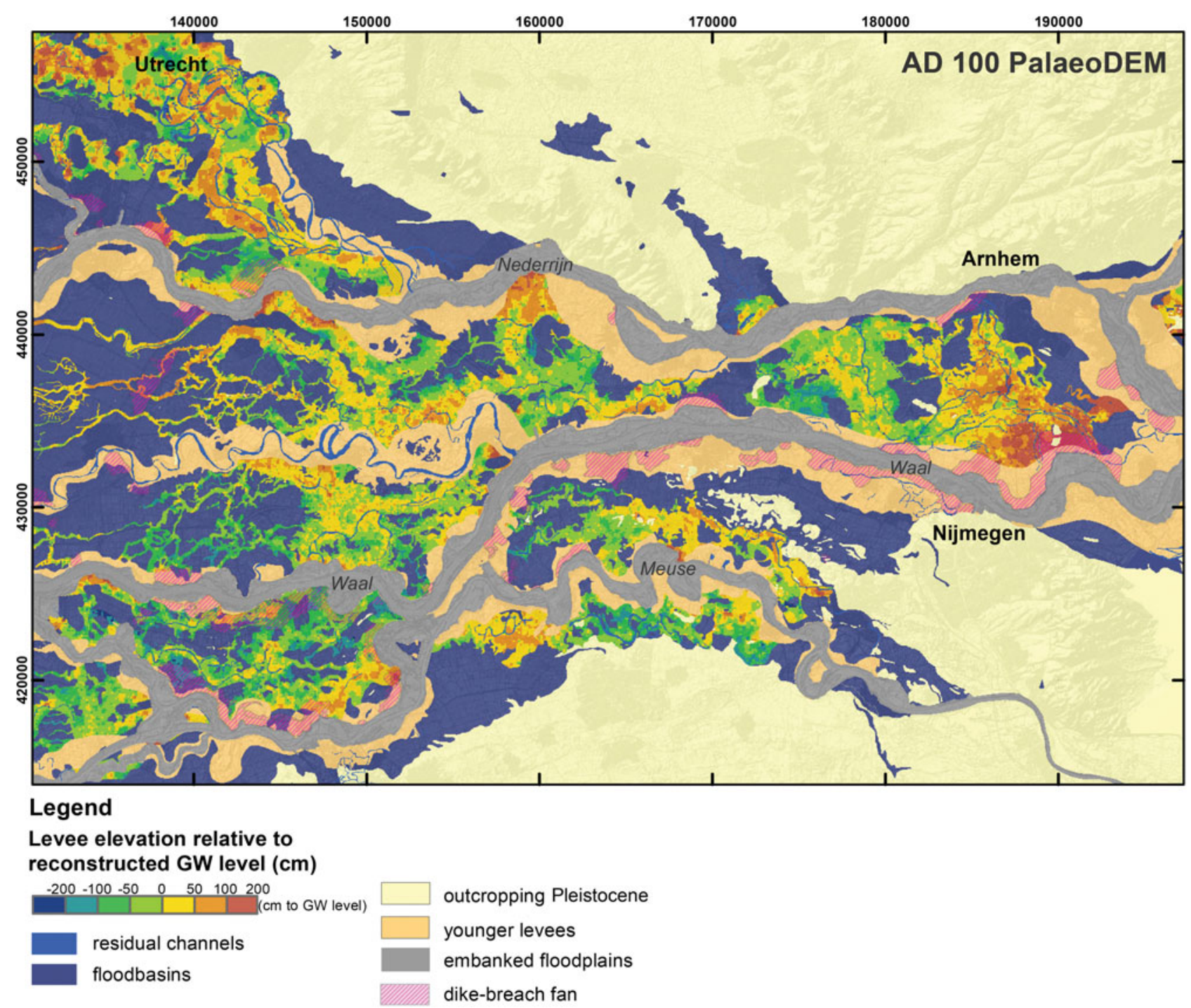

Fig. 3. Palaeo-elevation model of the Rhine-Meuse delta during the first millennium (adapted from Pierik et al., 2017).

\section{Method}

The relative impact of population fluctuations on past land use was modelled through the simulation of various land-use scenarios (Fig. 4). The number of simulated scenarios was determined by testing the feasibility of the archaeological hypotheses outlined above (Table 1).

\subsection{Palaeodemographic modelling}

In order to determine population numbers and fluctuations, palaeodemographics were reconstructed for each ABR subperiod (see Appendix A (available online at https://doi.org/10.1017/ njg.2018.3) for a detailed description). Total population numbers were determined by calculating the size of the rural population and adding the number of people living in exceptionally large settlements or in a military context.
Rural population Both during the Roman period and the Early Middle Ages the majority of people in the Rhine-Meuse delta lived in rural settlements. Larger settlements, in some cases very large, were exceptional. Rural population numbers per ABR subperiod were calculated by applying the following SDM to the study area:

$$
\mathrm{Rp}=\left(S_{\mathrm{v}}+S_{\mathrm{u}}\right) \times \delta \times \alpha
$$

Rp rural population

$S_{\mathrm{V}}$ number of verified settlements

$S_{\mathrm{u}}$ number of (probable) undiscovered settlements

$\delta$ average number of houses per settlement (constant)

$\alpha$ average number of individuals per house (constant)

In this equation rural population ( $R p)$ is calculated by multiplying the number of verified and (probable) undiscovered settlements $\left(S_{\mathrm{v}}\right.$ and $\left.S_{\mathrm{u}}\right)$ in an area by the average number of houses per settlement $(\delta)$, and by household size $(\alpha)$. The 



(A) PalaeoDEM
(B) Soil map of the Netherlands
(C) Geomorphological reconstructions AD 100, 500 and 900

Fig. 4. Flowchart of the PLUS land-use simulation model. Land-use suitability maps were compiled for $A D 100,500$ and 900 . Land-use suitability is based on elevation classes derived from the palaeo-elevation model (A; palaeo-DEM) and on geomorphology-based lithological reconstructions (C). Geomorphological data were refined using palaeo-elevation data $(A)$ and soil data $(B)$. Twenty land-use scenarios testing three archaeological hypotheses (Table 1) were calculated by combining the land-use suitability maps with detailed reconstructions of Roman and early-medieval population numbers (see Appendix $A$ (available online at https://doi.org/10.1017/njg.2018.3) for details).

total number of settlements is derived from both excavated and undiscovered settlement data, since archaeological research has demonstrated that in the Netherlands on average at least $50 \%$ of settlements are not (yet) discovered (Bult, 1983; Deuben et al., 2006). In the calculations we included only settlement data with a high chronological resolution, i.e. dating to a specific $A B R$ subperiod. The average number of houses per settlement and the average household size per ABR subperiod were determined based on estimates published in archaeological excavation reports and overview studies (Table 3; see Appendix A (available online at https://doi.org/10.1017/njg.2018.3) for a more detailed description of the archaeological data underlying these and other demographic estimates).

Large settlements Large settlements were classified based on a settlement size of $>5$ ha. We based population numbers for these large settlements on settlement size, building density of houses and average household size. Quantitative data from wellresearched and -documented large settlements, such as Roman Nijmegen and early-medieval Dorestad, were used as a reference frame for reconstructing population numbers in other, lessknown, contemporary large settlements.

Military presence During the Roman period the study area bordered on, and in part constituted, the northern frontier of the Roman Empire, and therefore was characterised by a substantial military presence (e.g. Van Es, 1981; Polak 2009). The estimates of the number of troops during the ERP, MRP and LRP are based on historical sources (e.g. containing information about size of Roman legions and fortresses) and archaeological studies (e.g. publications about excavated fortresses in the study region; see Appendix $A$, available online at 
Table 3. Average number of houses and household size per ABR subperiod based on (published) archaeological-excavation data. Sources were selected for sites and regions within and in direct vicinity of the study area.

\begin{tabular}{llll}
\hline Period & $\begin{array}{l}\boldsymbol{N} \text { houses per } \\
\text { settlement }\end{array}$ & $\begin{array}{l}\text { Average household } \\
\text { size }\end{array}$ & Source(s) \\
\hline ERP & 1.5 & 6.5 & Bloemers, 1978; Heeren, 2009; Vos, 2009; Dijkstra, 2011 \\
MRP & 3.0 & 6.5 & Bloemers, 1978; Heeren, 2009; Vos, 2009; Dijkstra, 2011 \\
LRP & 1.5 & 6.5 & Bloemers, 1978; Heeren, 2009; Vos, 2009; Dijkstra, 2011 \\
EMPA & 3.0 & 6.5 & Dijkstra, 2011 \\
EMPB & 3.0 & 6.5 & Dijkstra, 2011 \\
EMPC & 3.0 & 6.5 & Dijkstra, 2011 \\
EMPD & 5.0 & 6.5 & Hamerow, 2002; Dijkstra, 2011; Van Beek et al., 2015 \\
\hline
\end{tabular}

https://doi.org/10.1017/njg.2018.3). We used welldocumented military sites as a frame of reference for lessknown fortresses (Table 6, further below). Military presence in the palaeodemographic modelling includes Roman fortresses (castella and castra) and the associated civilian settlements (vici and canabae legionis). Based on research by Van Dinter et al. (2014) we have set the average size of military presence in the castella at 350 soldiers. Much less is known about the corresponding vici. Some have suggested that the number of people living in a vicus may have been twice the number of soldiers in the corresponding castellum (e.g. Sommer, 1984, 1991). Judging by the size and building-density of vici in the study area (e.g. Hazenberg, 2000; Ploegaert, 2006; Blom \& Vos, 2007; Vos et al., 2012; Waasdorp \& Van Zoolingen, 2015), this estimate must be too high. Van Dinter et al. (2014, p. 29) for the western part of the Dutch limes have concluded that their assumption of 350 soldiers per fort and an equal number of people living in the associated vicus could well be a maximum estimate. Therefore, we applied a $1: 1$ ratio in the palaeodemographic modelling. The exceptionally large Roman castra and canabae legionis at Nijmegen (c. AD 70-104) were modelled separately. Although both, according to most literature, date to the very beginning of the MRP, the Roman military presence in Nijmegen was a direct consequence of a preceding ERP event (the revolt of the Batavi in $\mathrm{AD}$ 69-70), and was not characteristic of the MRP. Subsequently we included these numbers in the ERP-population reconstruction.

\subsection{Land-use suitability}

A map of the suitability of the landscape for specific types of land use was separately reconstructed for $\mathrm{AD} 100,500$ and 900. Land-use suitability was determined for each geomorphological unit based on the ecological preferences of different vegetation types (Westhoff et al., 1970a,b,c; Weeda et al., 1985, 1987, 1988, 1991, 1994, 2000, 2003, 2005). Allocation factors were ascertained based on a combination of geomorphological units, palaeo-surface elevation data and lithological data (see Appendix B (available online at https://doi.org/10.1017/njg. 2018.3) for a detailed description). Based on the predefined archaeological hypotheses (Table 1) and in line with Kooistra et al. (2013) and Van Dinter et al. (2014) we have differentiated between three specific land-use types: arable farming, pasture and meadow (Appendix B, available online at https://doi.org/ 10.1017/njg.2018.3). Each geomorphological unit was given a value ranging from 0 to 5 , with a value of 0 reflecting no potential and 5 reflecting the highest potential for a specific type of land use. The current model exclusively focused on reconstructing the impact of palaeodemographics on arable farming, pastures and meadows. Therefore it excludes processes such as logging and woodland regeneration and we kept the amount of woodland constant for all scenarios.

\subsection{Land-use modelling}

The land-use suitability data and palaeodemographic data were integrated in a newly adapted PLUS for the fluvial-dominated part of the Rhine-Meuse delta.

Integrating cultural and environmental data Land-use scenarios were modelled using the geomorphological reconstructions for AD 100, 500 and 900 (Section 3.2). Settlement data per ABR subperiod (Table 2) were integrated by converting them to fit the chronological resolution of the geomorphological time slices (Fig. 5). We applied the same 'ABR subperiod to geomorphological time slice' conversion as Van Lanen \& Pierik (2017) already performed for the same research area, with the $\mathrm{AD} 100$ time slice reflecting the ERP and MRP, the $A D 500$ time slice the LRP, EMPA and EMPB and the AD 900 time slice the EMPC and EMPD.

The PLUS model Originally the PLUS modelling framework was developed for the Lower Rhine delta in the western Netherlands (De Kleijn et al., in press). This initial PLUS has integrated calculations derived from a conceptual model which reconstructs whether or not the local population could have supplied the Roman army in this region with food (Kooistra et al., 2013; Van Dinter et al., 2014). By integrating data from this conceptual model in this initial PLUS the applicability of the modelling framework for calculating past land use was demonstrated. 


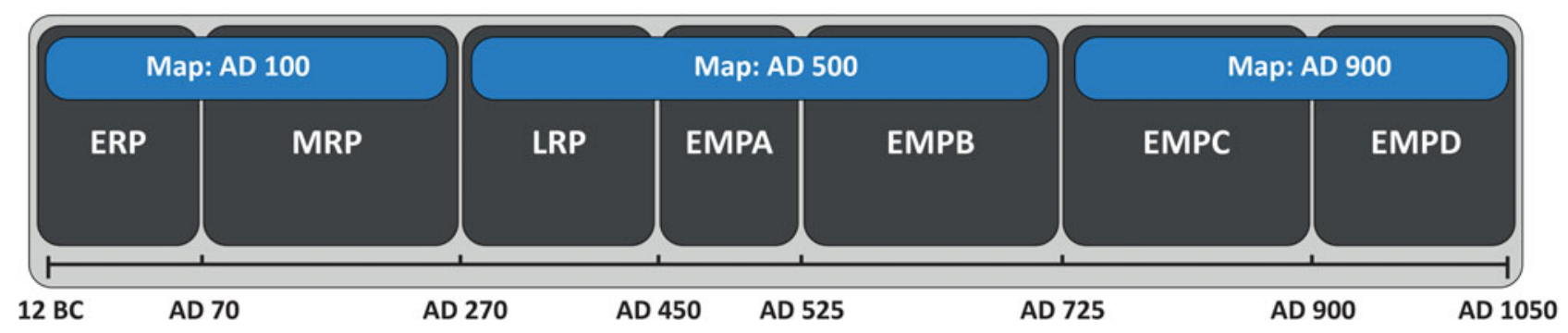

Fig. 5. Chronological division of subperiods based on the Archaeological Basic Register: early-Roman period (ERP), middle-Roman period (MRP), late-Roman period (LRP), early-medieval period A (EMPA), early-medieval period B (EMPB), early-medieval period C (EMPC) and early-medieval period D (EMPD). Each subperiod was linked to a single geomorphological-landscape reconstruction representing the situation in C. AD 100,500 or 900.

In the present study we apply a similar PLUS to the central and upstream parts of the Rhine-Meuse delta, chronologically expanding it to cover the whole of the first millennium, and adapting it to further explore its potential to test the feasibility of archaeological hypotheses (Table 1). The model uses the gridcell resolution $(100 \times 100 \mathrm{~m})$, software and land-use modelling 'rules' on energy intake, average yield, and distance relations defined by De Kleijn et al. (in press; Appendices B and C, available online at https://doi.org/10.1017/njg.2018.3). The PLUS applied in this paper is based on the assumption that the landuse modelling 'rules' are valid for the whole of the first millennium $\mathrm{AD}$. The model was designed to simulate 20 land-use scenarios fully testing the feasibility of the archaeological hypotheses under investigation (Table 8, further below; Appendix D, available online at https://doi.org/10.1017/njg.2018.3). Following the three hypotheses, scenarios 1-14 calculate the possibility of the natural landscape providing sufficient arable land, meadows and pastures in order to remain self-sufficient during the first millennium. Scenarios 15-18 specifically focus on the impact of Roman military population numbers, and scenarios 19 and 20 deal with the influence of early-medieval Dorestad, which was an exceptionally large trade centre. As already stated, archaeological research indicates that (at least) $50 \%$ of the firstmillennium settlements in the present-day Netherlands are still undiscovered (Section 4.1). To compensate for this discrepancy, we calculated land-use scenarios based on two settlement settings: (1) using excavated settlements only; and (2) using excavated settlements plus the same amount of undiscovered settlements (Table 8, further below). Additionally, scenarios 17-20 include the impact of possibly imported food on local landscapebased production requirements.

\section{Results}

\subsection{Demographic reconstructions}

During the Roman period major shifts in rural population size occurred, consisting of a strong rise towards the MRP and an equally strong decline during the LRP (Table 4). The same trend holds for the end of the Early Middle Ages, during the EMPC and EMPD. Most notable is the population decline between the MRP and LRP, when rural population in the Rhine-Meuse delta decreased by $79.5 \%$. Rural population remained low until the EMPC, after which a steady rise occurred which continued during the remainder of the Early Middle Ages.

Large settlements Large settlements were rare during the first millennium $A D$ and only few could be identified for the MRP, EMPB, EMPC and EMPD (Table 5; Fig. 6; Appendix A, available online at https://doi.org/10.1017/njg.2018.3). During the MRP the first signs of low-level urbanisation occurred, with rural centres developing at Elst, Cuijk, Rossum and Wijchen. The largest settlement during the MRP however developed at Nijmegen, consisting of the Roman town Ulpia Noviomagus Batavorum (c. 5000 inhabitants). In line with the drop in rural population, no large settlements are known in the following LRP. The first post-Roman large settlements, clearly smaller than their Roman predecessors, appeared again in the eastern part of the study area during the EMPB at the present towns of Nijmegen and Lent. The most notable influx of people living in large settlements occurred during the EMPC with the development of Dorestad. As already stated, this early-medieval emporium was exceptionally large.

Military presence Archaeological data about military presence are only available for the Roman period. During the ERP and MRP 15 Roman fortresses, consisting of 14 castella and 1 castra accompanied by an equal number of vici and canabae legionis, were located in (the direct vicinity of) the study area (Table 6; Fig. 7; Appendix A, available online at https://doi. org/10.1017/njg.2018.3). During the (end of the) ERP, military numbers were much higher than during the MRP, which was mainly due to the short presence of the 10th legion at the castra in Nijmegen (Appendix A, available online at https: //doi.org/10.1017/njg.2018.3).

After the collapse of the Roman limes around AD 270, Roman military presence in the Rhine-Meuse delta declined significantly. Due to several changes in Roman defence policy, such as the introduction of the limitanei (e.g. Van Daele, 2003) 
Table 4. Estimated rural population in the study area based on archaeological data, building density and household size.

\begin{tabular}{|c|c|c|c|c|c|c|}
\hline \multicolumn{7}{|c|}{ Rural settlements } \\
\hline Period & $N$ settlements & $\begin{array}{l}N \text { settlements incl. } \\
\text { undiscovered sites }\end{array}$ & $\begin{array}{l}\text { Avg houses per } \\
\text { settlement }\end{array}$ & $N$ houses & $\begin{array}{l}\text { Household } \\
\text { size }\end{array}$ & Population \\
\hline ERP & 1234 & 2468 & 1.5 & 3702 & 6.5 & 24,063 \\
\hline MRP & 1619 & 3238 & 3 & 9714 & 6.5 & 63,141 \\
\hline LRP & 664 & 1328 & 1.5 & 1992 & 6.5 & 12,948 \\
\hline EMPA & 306 & 612 & 3 & 1836 & 6.5 & 11,934 \\
\hline EMPB & 428 & 856 & 3 & 2568 & 6.5 & 16,692 \\
\hline EMPC & 818 & 1636 & 3 & 4908 & 6.5 & 31,902 \\
\hline EMPD & 711 & 1422 & 5 & 7110 & 6.5 & 46,215 \\
\hline
\end{tabular}

Table 5. Overview of Roman and early-medieval large settlements located in the study area.

\begin{tabular}{|c|c|c|c|c|}
\hline Period & Name & $\begin{array}{l}\text { Surface } \\
\text { (ha) }\end{array}$ & People & $\begin{array}{l}\text { Source(s) (based on either population or surface } \\
\text { reconstructions) }\end{array}$ \\
\hline \multirow{6}{*}{ MRP (AD 70-270) } & Nijmegen & 40 & 5000 & Brunsting, 1937; Willems and Van Enckevort, 2009 \\
\hline & Elst & 15 & 1875 & Willems, 1986 \\
\hline & Cuijk & 10 & 1250 & Van Enckevort and Thijssen, 2002 \\
\hline & Rossum & 5 & 625 & \multirow{3}{*}{$\begin{array}{l}\text { Little known on these settlements. However, clearly smaller } \\
\text { in size and also no signs of (monumental) stone building } \\
\text { which is characteristic for vici according to Hiddink, } 1991 \text {. } \\
\text { Extrapolated based on the vicus of Elst. }\end{array}$} \\
\hline & Wijchen & 5 & 625 & \\
\hline & Total & 75 & 9375 & \\
\hline \multirow{3}{*}{ EMPB (AD 525-725) } & Nijmegen & 10 & 500 & Den Braven, 2014; Hendriks et al., 2014 \\
\hline & Lent & 10 & 500 & Harmsen et al., 2012 \\
\hline & Total & 20 & 1000 & \\
\hline \multirow{4}{*}{ EMPC (AD 725-900) } & Dorestad & 100 & 10,000 & Van Es and Vewers, 2015 \\
\hline & Nijmegen & 10 & 1000 & Kuys and Bots, 2005; Den Braven, 2014; Hendriks et al., 2014 \\
\hline & Utrecht & 20 & 500 & Renes, 2005; Van Rooijen 2010 \\
\hline & Total & 130 & 11,500 & \\
\hline \multirow{4}{*}{ EMPD (AD 900-1050) } & Nijmegen & 10 & 1000 & Kuys and Bots, 2005; Den Braven, 2014 \\
\hline & Tiel & 12 & 600 & Oudhof et al., 2013 \\
\hline & Utrecht & 20 & 1000 & Renes, 2005; Van Rooijen 2010 \\
\hline & Total & 42 & 2600 & \\
\hline
\end{tabular}

and declining Roman influence in the area, the number of military sites after AD 270 was significantly lower than during the ERP and MRP (Table 6; Appendix A, available online at https://doi.org/10.1017/njg.2018.3).

Total-population estimates, Rhine-Meuse delta Palaeodemographics were reconstructed based on rural population numbers, large settlements, and military presence (Table 7; Fig. 8). Calculated total estimates show the same trend as the rural population fluctuations, underlining the dominant influence of rural population numbers on first-millennium palaeodemographics. A strong population increase occurred during the MRP (43.2\%), mainly facilitated by a growth of rural population numbers as well as by an increase of large settlements. A significant population decline occurred during the LRP (by 78.7\%), mainly due to an overall decrease of rural population numbers and large settlements, and a decreased military presence. Significant demographic growth occurred from the EMPC onwards. During the heydays of Roman occupation, the MRP, Roman military presence was relatively low and the level of urbanisation was high (Table 7). However, the highest level of urbanisation occurred during the EMPC, mainly due to the development of a trade centre at Dorestad (26.5\%). 
Table 6. Military presence in the study area during the Roman period. Calculations are based on historical sources, archaeological data and (for the LRP) on oral communication of Dr S. Heeren. See Appendix A (available online at https://doi.org/10.1017/njg.2018.3) for a complete list of castella and castra names including corresponding population numbers.

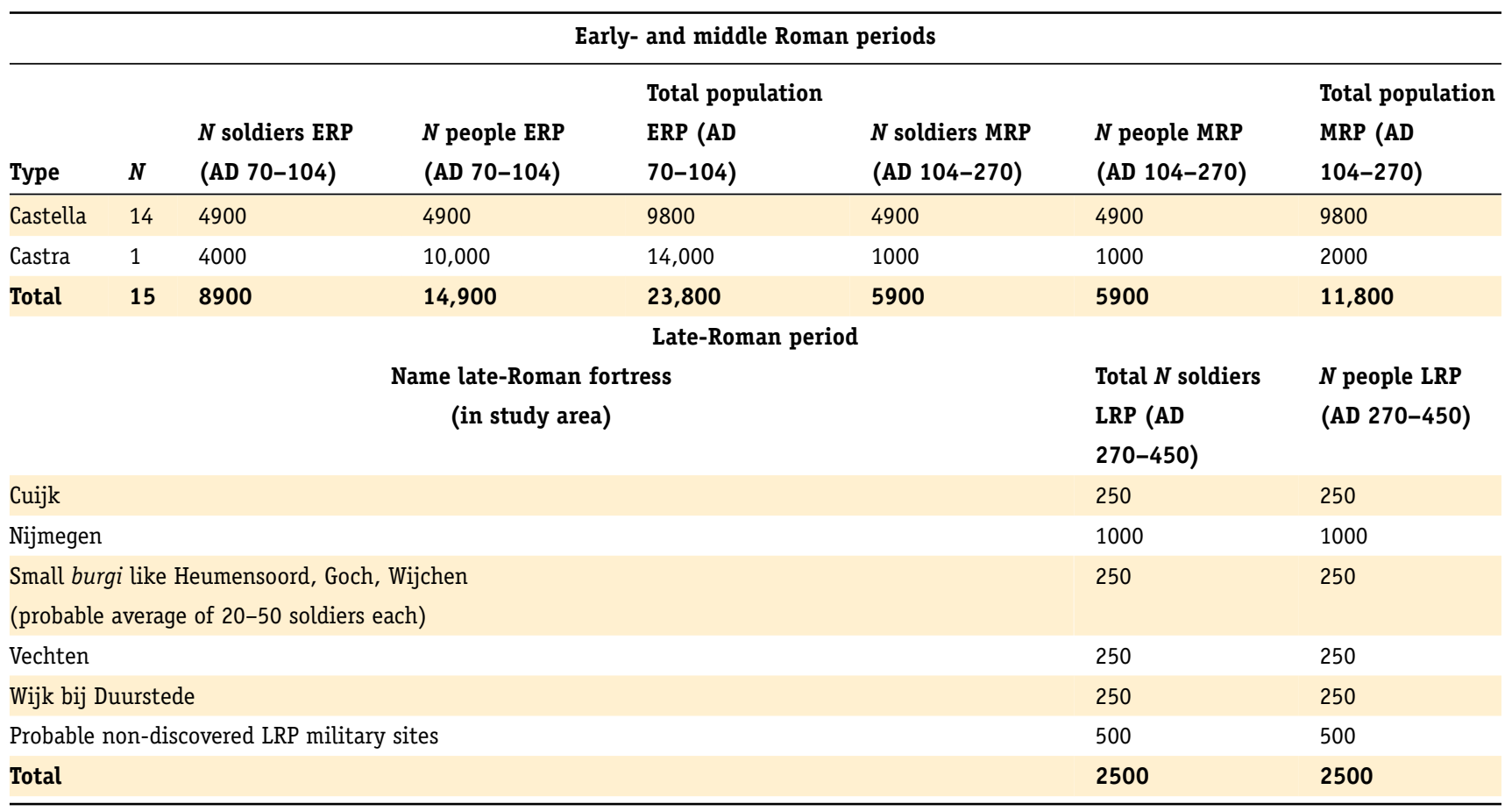

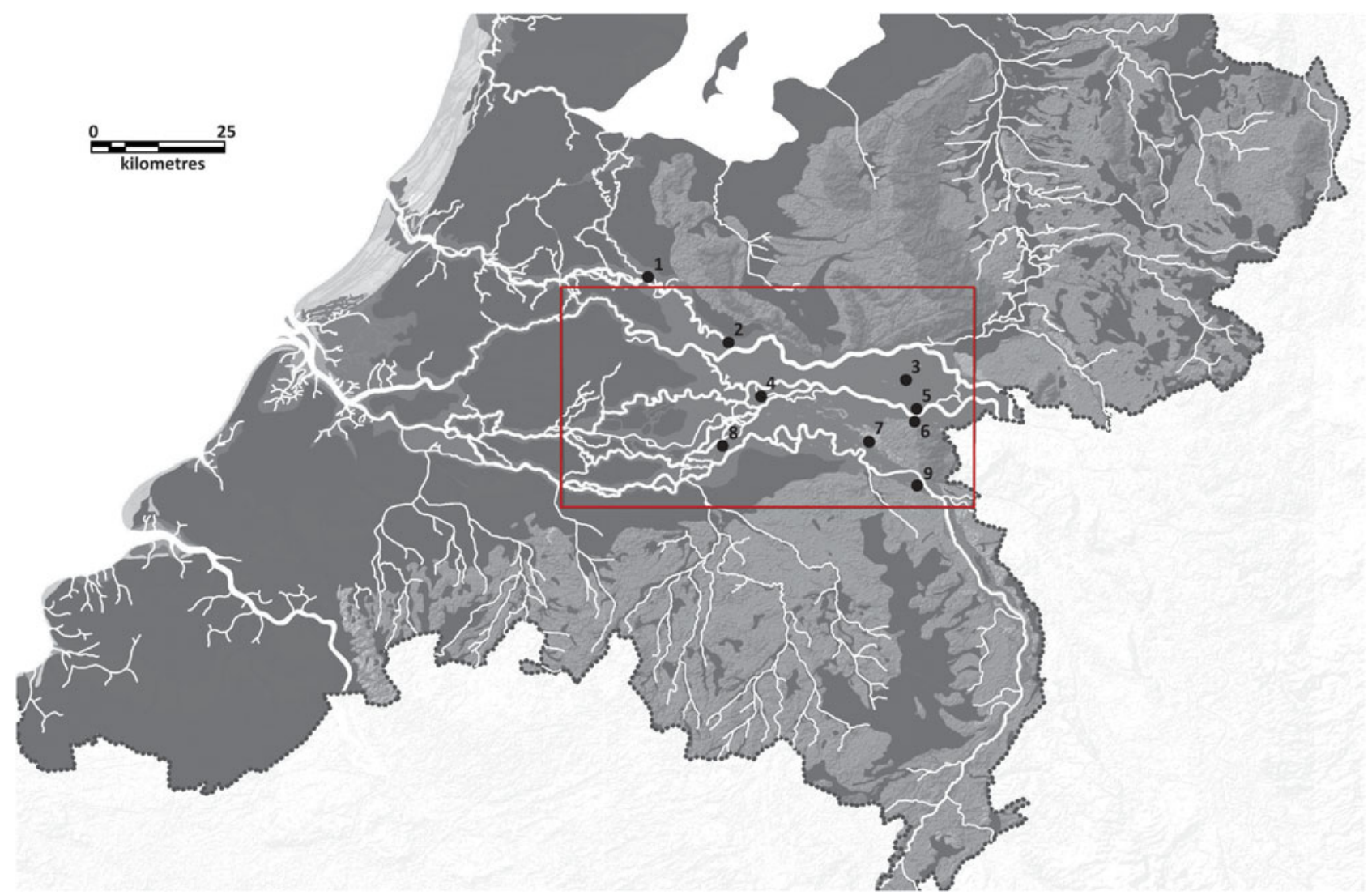

Fig. 6. Large settlements in and near the study area: $1=$ Utrecht, $2=$ Dorestad, $3=$ Elst, $4=$ Tiel, $5=$ Lent, $6=$ Nijmegen, $7=$ Wijchen, $8=$ Rossum and $9=$ Cuijk. Data are overlain on the palaeogeographic reconstruction of $A D$ 100, adapted from Vos \& De Vries (2013). 
Table 7. Estimated total population in the study area based on archaeological data, settlement size, structure and density. For each ABR subperiod the relative contribution of military presence (i.e. active soldiers) and urbanisation on total population numbers is provided.

\begin{tabular}{llllll}
\hline Period & $\begin{array}{l}\text { Total population } \\
\text { study area }\end{array}$ & $\begin{array}{l}\text { Rural population }+ \\
\text { military presence }\end{array}$ & $\begin{array}{l}\text { Rural population }+ \\
\text { large settlements }\end{array}$ & $\begin{array}{l}\text { Rural } \\
\text { population }\end{array}$ & $\begin{array}{l}\text { \% low-level } \\
\text { urbanisation military }\end{array}$ \\
\hline ERP & 47,863 & 47,863 & 24,063 & 24,063 & 24.9 \\
MRP & 84,316 & 74,941 & 72,516 & 63,141 & 7.9 \\
LRP & 17,948 & 17,948 & 12,948 & 12,948 & 14.0 \\
EMPA & 11,934 & 11,934 & 11,934 & 11,934 & 0 \\
EMPB & 17,692 & 16,692 & 17,692 & 16,692 & 0 \\
EMPC & 43,402 & 31,902 & 43,402 & 31,902 & 0 \\
EMPD & 48,815 & 46,215 & 48,815 & 46,215 & 0 \\
\hline
\end{tabular}

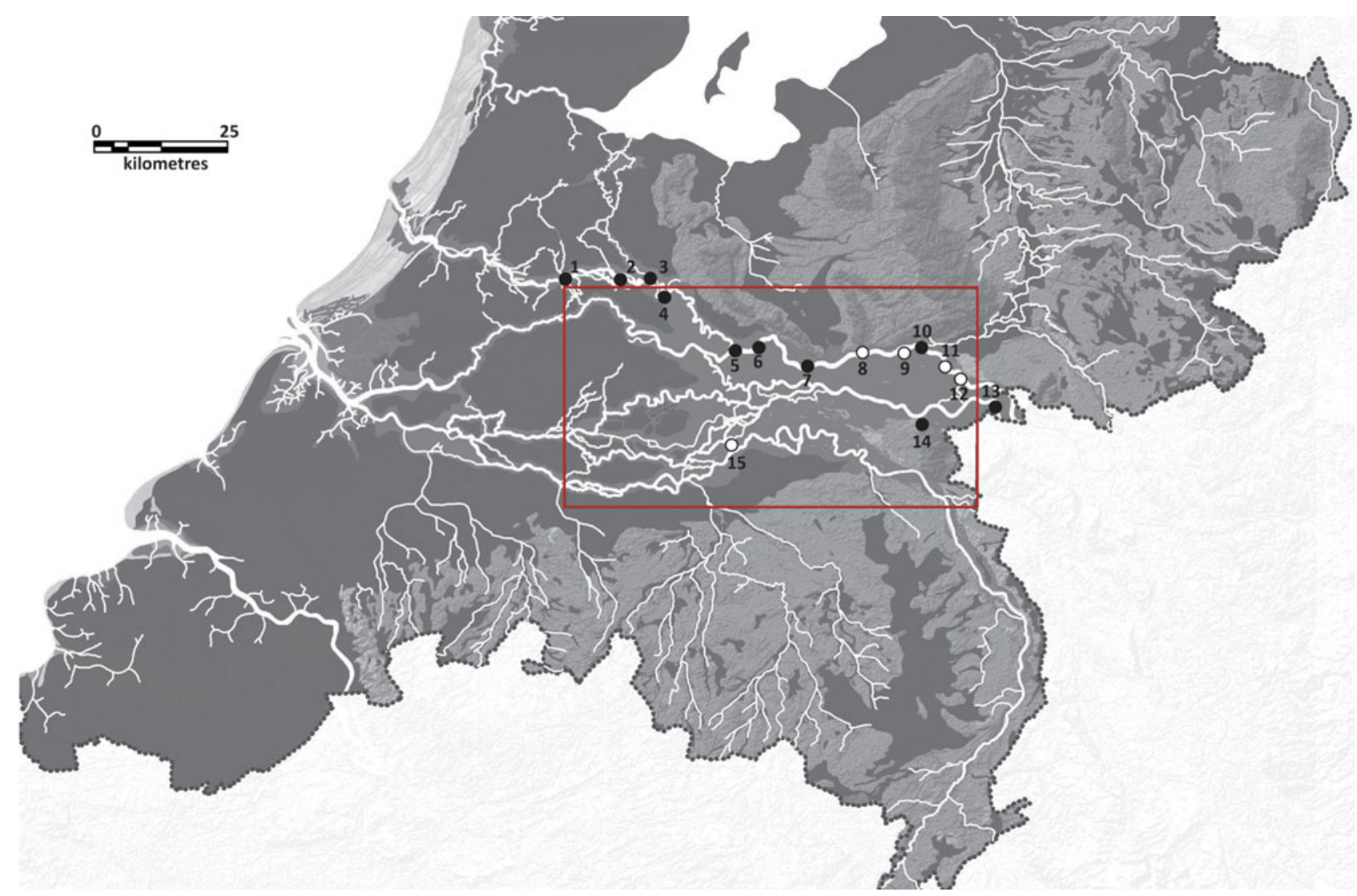

Fig. 7. Roman military sites in and near the study area: $1=$ Woerden, $2=$ Utrecht: De Meern, $3=$ Utrecht: Domplein, $4=$ Vechten, $5=$ Rijswijk, $6=$ Maurik, $7=$ Kesteren, $8=$ Randwijk, $9=$ Driel, $10=$ Arnhem, $11=$ Huissen, $12=$ Duiven, $13=$ Herwen, $14=$ Nijmegen and $15=$ Rossum. Certain locations are depicted in black (circles), uncertain and approximate locations in white (circles). Data are overlain on the palaeogeographic reconstruction of $A D 100$, adapted from Vos \& De Vries (2013).

\subsection{Land-use scenario modelling}

The tested archaeological hypotheses are (Table 1): (1) inhabitants of the study area were self-sufficient in terms of food supply during the whole of the first millennium AD (Section 5.2.1); (2) during the first centuries of this millennium Roman military presence had major consequences in terms of food supply and landscape (Section 5.2.2); and (3) the development of Dorestad had major consequences in terms of food supply and landscape during the Early Middle Ages (Section 5.2.3).

5.2.1. Hypothesis 1: self-sufficient food supply during the first millennium $A D$. The possibility of self-sufficiency in terms of food supply during the first millennium $A D$ was tested in scenarios 1-14, scenario groups (SGs) 1 and 2 (Table 8; Fig. 9). In SG 1 the options for self-sufficiency were simulated per ABR 


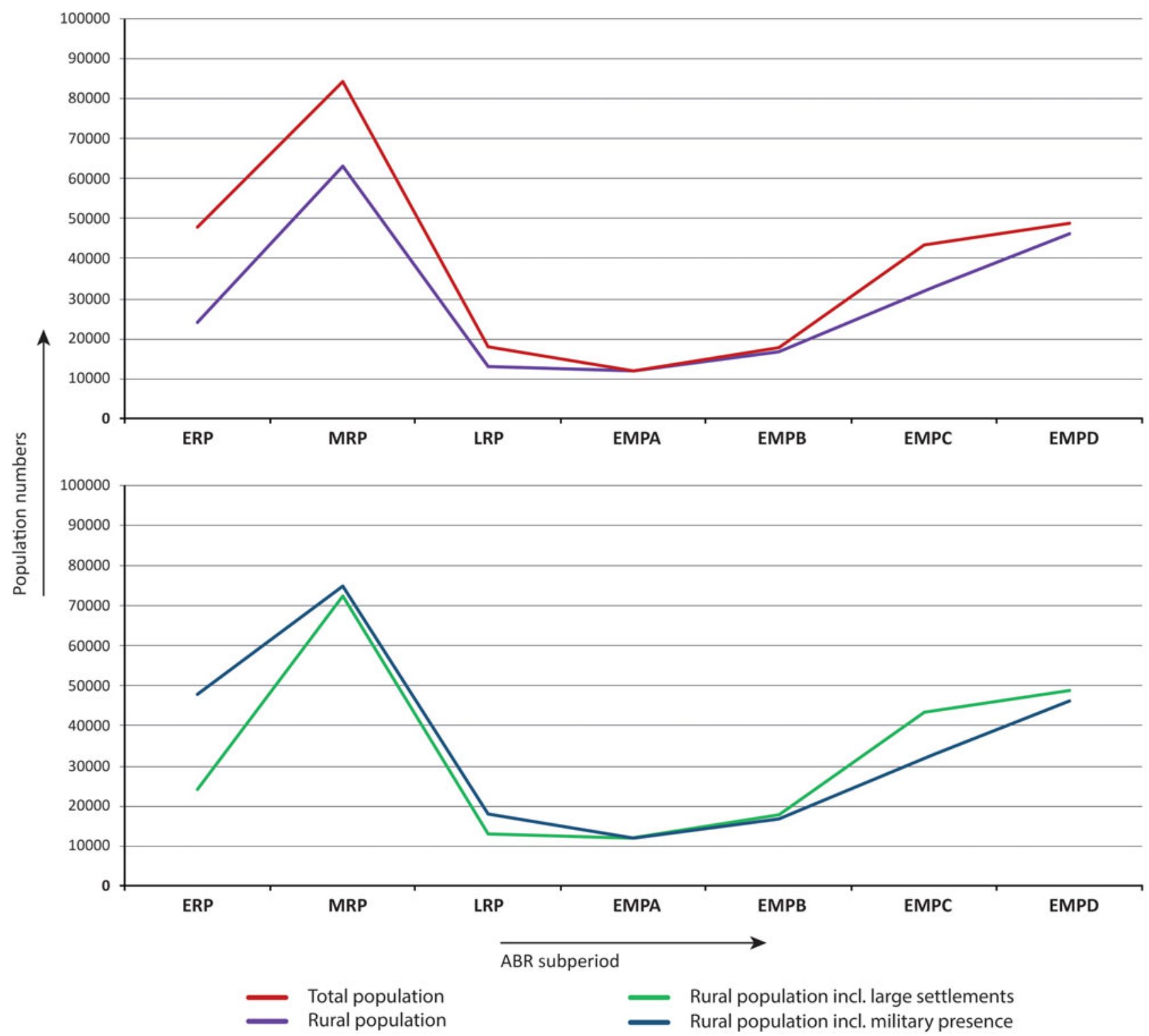

Fig. 8. Reconstructed palaeodemographic trends in the Rhine-Meuse delta during the first millennium AD. For each of the ABR subperiods the total population size, the number of rural inhabitants, the number of large-settlement inhabitants and the number of the military population are given.

subperiod based on the minimum numbers of settlements, i.e. only using the number of excavated sites. In SG 2 these same options were simulated, but now assuming that $50 \%$ of the settlements are not yet discovered (i.e. using the maximum number of settlements; Section 4.1). Results show that in 13 of the 14 tested scenarios self-sufficiency for rural and large settlements was not a problem in the study area (Table 8; Fig. 9). Even with the maximum number of settlements, during most $A B R$ subperiods the landscape provided abundant space for arable land, meadows and pastures. Only in scenario 14 (SG 2) did population impact result in such a high demand that the models' boundary conditions for the EMPD were exceeded. Within the defined model settings (Section 4.3; Appendices $\mathrm{B}$ and $\mathrm{C}$ ) the high demand resulted in a situation in which the natural landscape provided insufficient land-use options. In this scenario, the model simulates the specific challenge of producing sufficient surplus to also provide for the larger settlements during this period. This is also demonstrated by the fact that all grid cells were designated for a specific type of land use (unused land = null), suggesting that the landscape within the model settings was used to its full potential (Fig. 9A-D).

5.2.2. Hypothesis 2: the impact of Roman military presence. The impact of Roman military presence was calculated for the ERP and MRP in land-use scenarios 15-18 (SGs 3 and 4; Table 8). First, we analysed the hypothetical situation in which the study area contained the maximum number of settlements, and in which the Roman army and large settlements were supplied exclusively using locally produced food. Second, we calculated the impact of Roman military presence for the situation in which the study area contained the minimum number of settlements and 
Table 8. Land-use scenario calculations based on the predefined hypotheses (Table 1). Hypothesis $1=$ scenarios 1-14, hypothesis $2=$ scenarios 15-18, and hypothesis 3 = scenarios 19 and 20. The calculated numbers depict the degree of realisation, i.e. the extent to which the demand could be met $(1=100 \%$ and $0=0 \%)$, and 'NULL' indicates no grid cells containing this type of land use. See Appendices B, C and D (available online at https://doi.org/ 10.1017/njg.2018.3) for a detailed description of the applied methods, the calculated numbers and each scenario.

\begin{tabular}{|c|c|c|c|c|c|c|c|}
\hline \multicolumn{2}{|c|}{ ABR subperiod } & \multirow[t]{2}{*}{$\begin{array}{l}\text { Land-use } \\
\text { scenario \# }\end{array}$} & $\begin{array}{l}\text { Arable farming } \\
\text { (self-sufficient) }\end{array}$ & $\begin{array}{l}\text { Arable farming } \\
\text { (surplus) }\end{array}$ & \multirow[t]{2}{*}{ Pasture } & \multirow[t]{2}{*}{ Meadow } & \multirow[t]{2}{*}{$\begin{array}{l}\text { Map in } \\
\text { Figure } 9\end{array}$} \\
\hline \multicolumn{4}{|c|}{ Hypothesis 1: self-sufficiency } & & & & \\
\hline \multicolumn{8}{|c|}{ Scenario group 1} \\
\hline ERP & 12 BC-AD 70 & 1 & 1.003 & 1.005 & 0.999 & 0.999 & - \\
\hline MRP & AD 70-270 & 2 & 1.078 & 1.011 & 0.997 & 0.994 & $\mathrm{~A}$ \\
\hline LRP & AD 270-450 & 3 & 1.000 & NULL & 0.999 & 0.999 & - \\
\hline EMPA & AD 450-525 & 4 & 1.006 & NULL & 1.000 & 0.999 & - \\
\hline EMPB & AD 525-725 & 5 & 1.076 & 1.011 & 1.000 & 0.997 & - \\
\hline EMPC & AD 725-900 & 6 & 1.106 & 1.011 & 0.995 & 0.992 & - \\
\hline EMPD & AD 900-1050 & 7 & 1.199 & 1.011 & 0.982 & 0.977 & C \\
\hline \multicolumn{8}{|c|}{ Scenario group 2} \\
\hline ERP & 12 BC-AD 70 & 8 & 1.047 & 1.007 & 0.999 & 0.997 & - \\
\hline MRP & AD 70-270 & 9 & 1.213 & 0.974 & 0.931 & 0.925 & B \\
\hline LRP & AD 270-450 & 10 & 1.013 & NULL & 0.999 & 0.999 & - \\
\hline EMPA & AD 450-525 & 11 & 1.057 & NULL & 1.001 & 0.999 & - \\
\hline EMPB & AD 525-725 & 12 & 1.211 & 1.021 & 0.990 & 0.984 & - \\
\hline EMPC & AD 725-900 & 13 & 1.229 & 1.006 & 0.969 & 0.965 & - \\
\hline EMPD & AD 900-1050 & 14 & 1.071 & 0.852 & 0.816 & 0.812 & $\mathrm{D}$ \\
\hline \multicolumn{8}{|c|}{ Hypothesis 2: Roman military } \\
\hline \multicolumn{8}{|c|}{ Scenario group 3} \\
\hline ERP & 12 BC-AD 70 & 15 & 1.051 & 1.008 & 0.997 & 0.995 & $\mathrm{E}$ \\
\hline MRP & AD 70-270 & 16 & 1.280 & 1.009 & 0.963 & 0.957 & G \\
\hline \multicolumn{8}{|c|}{ Scenario group 4} \\
\hline ERP & 12 BC-AD 70 & 17 & 1.004 & NULL & 0.999 & 0.999 & $\mathrm{~F}$ \\
\hline MRP & AD 70-270 & 18 & 1.096 & NULL & 0.991 & 0.987 & $\mathrm{H}$ \\
\hline \multicolumn{8}{|c|}{ Hypothesis 3: impact Dorestad } \\
\hline \multicolumn{8}{|c|}{ Scenario group 5} \\
\hline EMPC & AD 725-900 & 19 & 1.234 & 1.006 & 0.969 & 0.964 & I \\
\hline \multicolumn{8}{|c|}{ Scenario group 6} \\
\hline EMPC & AD 725-900 & 20 & 1.115 & 1.011 & 0.993 & 0.989 & $\mathrm{~J}$ \\
\hline
\end{tabular}

in which the large settlements were supplied with food through import. The results show that in all four scenarios despite major impact differences, the landscape in the delta provided sufficient opportunities to produce food for the Roman military occupation and was not a limiting factor (Table 8; Fig. 9E-H).

5.2.3. Hypothesis 3: the impact of early-medieval Dorestad. In order to determine the impact of the estimated 10,000 inhabitants of early-medieval Dorestad we calculated two scenarios, 19 and 20 (SGs 5 and 6; Appendix D, available online at https://doi.org/10.1017/njg.2018.3). In combination with scenario 13 , these scenarios depict the maximum number of settlements in the study area and calculate the claim on the nat- ural landscape in the hypothetical situations that Dorestad was supplied locally (zero food import), by 50\% food import outside the study area, and by $100 \%$ food import outside the study area. The results of these scenarios show a limited impact of the 10,000 inhabitants of Dorestad on the natural landscape (Table 8; Fig. 9I-J), which implies that even during the more densely populated EMPC, abundant options for arable farming, meadows and pastures were available in the study area. The different scale of impact between scenarios 19 and 20 underlines the relatively large impact of import on the natural-landscape demand. Despite this clear difference, the amount of import was not a decisive factor as the natural was not a limiting factor in either of the simulations. 

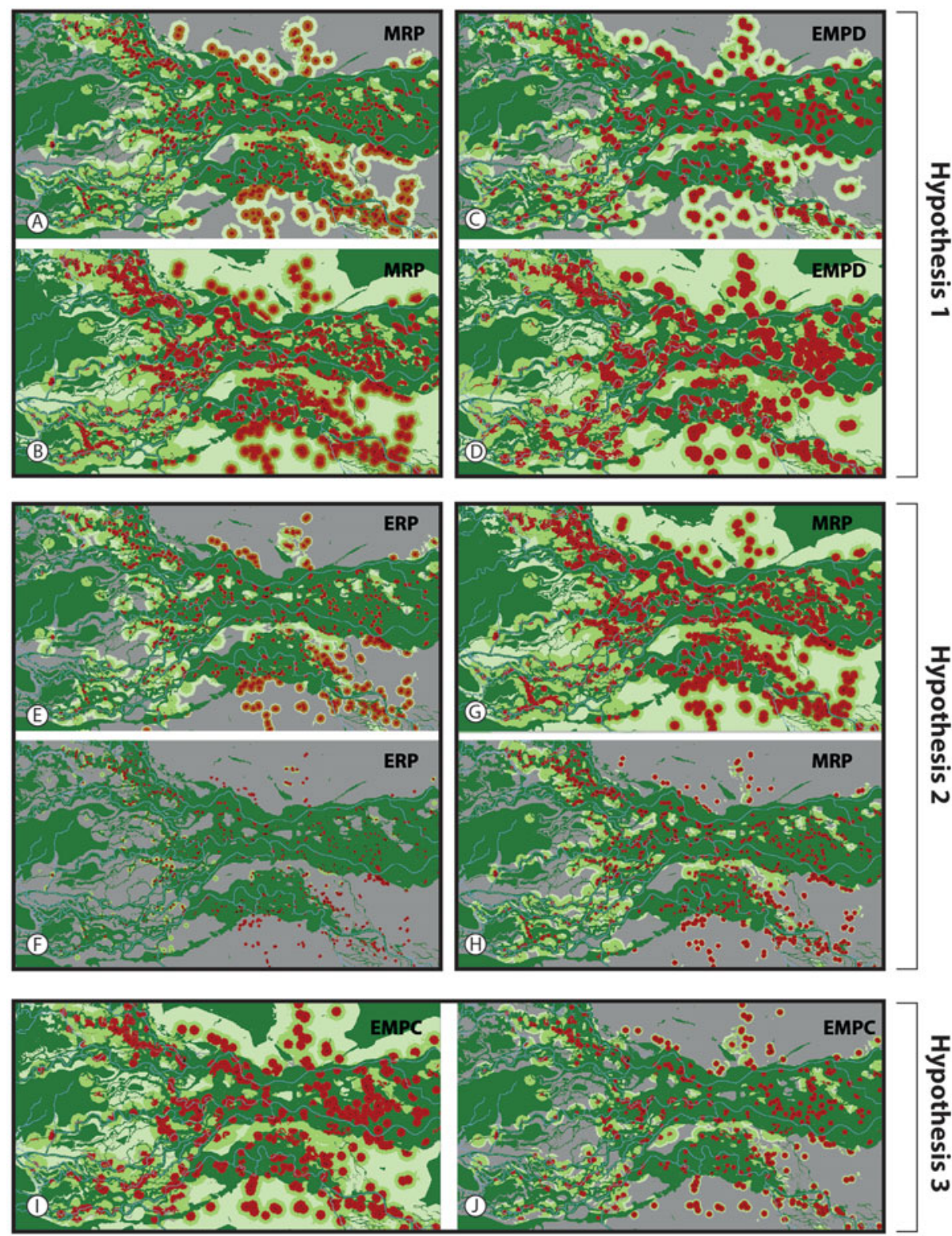

\section{Legend}
- Settlements
$\square$ Meadow
Arable self-sufficient
Arable surplus
Woodland (constant)
Unused land
$\square$ Pasture

Fig. 9. Selected land-use scenarios calculated by PLUS. Hypothesis 1 (Table 1): selection of ABR subperiods MRP (A and B) and EMPD (C and D). MRP: $(A)=$ scenario type: self-sufficiency simulation based on minimum number of settlements, $(B)=$ scenario type: self-sufficiency simulation based on maximum number of settlements. EMPD: $C=$ scenario type: self-sufficiency simulation based on minimum number of settlements, $(D)=$ scenario type: self-sufficiency simulation based on maximum number of settlements. The scenarios depicted in $B$ and $D$ show that the landscape was used to its full potential and that self-sufficiency was hard to obtain (B) or even unobtainable (D). Hypothesis 2 (Table 1): impact of the Roman army during the ERP and MRP in the four simulated scenarios $(E-H)$. ERP: $(E)=$ scenario type: maximum number of settlements locally provided food for both military sites and large settlements, $(F)=$ scenario type: minimum number of settlements locally provided food for only military sites, and large settlements depended on imported food. MRP: $(G)=$ scenario type: maximum number of settlements locally provided food for both military sites and large settlements, $(H)=$ scenario type: minimum number of settlements locally provided food for only military sites, and large settlements depended on imported food. Hypothesis 3 (Table 1): impact of Dorestad on the natural landscape (through an increasing food demand) during the EMPC in the two simulated scenarios (I and J). EMPC: (I) = scenario type: the maximum number of settlements were self-sufficient and provided $50 \%$ of the food demand of Dorestad, $(\mathrm{J})=$ scenario type: the maximum number of settlements were self-sufficient and Dorestad was provided with 100\% imported food. The corresponding land-use scenarios (SC) are (Table 8): A = Sc2, $B=S c 9, C=S c 7, D=S c 14, E=S c 15, F=S c 17, G=S c 16, H=S c 18, I=S c 19$, and J = Sc20. Please note: Since the model does not include processes such as logging or woodland regeneration we have kept the amount of woodland constant for all scenarios. Consequently this landscape unit equals unused land and does not influence the modelling outcome. 


\section{Discussion}

\subsection{Scenario modelling}

Thirteen of the 14 tested scenarios for hypothesis 1 indicate that the natural landscape in the study region during the first millennium $\mathrm{AD}$ was not a limiting factor for self-sufficiency in terms of food supply. This implies that in general the landscape of the Rhine-Meuse delta provided sufficient options for arable farming, meadows and pastures during the first millennium AD (Section 5.2; Table 8). The results additionally demonstrate that the PLUS modelling framework, which was initially designed for predicting land-use development in the future, is useful for reconstructing bandwidths of past cultural-landscape change. Only one of the simulations, scenario 14 , showed that self-sufficiency during the EMPD was hard to obtain. In addition, scenario 9 showed that obtaining self-sufficiency during this period required the full use of the landscape (Table 8). These deviating results are caused by the fact that these scenarios used the maximum number of settlements (Section 4.1). This might indicate that the assumed maximum number of undiscovered settlements (equal to the number of known settlements) is too high for this particular region and should be reassessed, or food was obtained from regions outside of the study area.

The PLUS applied in this paper is a first exploration of the applicability of simulation modelling as a means of testing existing archaeological hypotheses regarding past land use in the Netherlands. The applied model was derived from a similar PLUS developed for the Lower Rhine region during the ERP and MRP in the western Netherlands (De Kleijn et al., in press; also see this paper for a more detailed discussion on the full application potential of the PLUS framework). In the PLUS presented in the current study we assume that distance relations such as the maximum travel time from settlement to field, pasture or meadow remained relatively constant throughout the first millennium. Although the model primarily has a hypothesis-testing purpose, increasing the differentiation in land-use rules between the Roman and early-medieval periods (e.g. including socio-economic differences) might allow for a more in-depth assessment of the full reconstructive potential of the PLUS framework.

The current model exclusively focuses on reconstructing the impact of palaeodemographics on arable farming, pastures and meadows. As such we kept the areal extent of woodland constant for all scenarios. As an artefact of this assumption, the maps now suggest that wood was preferentially present on levees, whereas meadows and pastures occurred in the adjacent floodbasins. This causes woodland on levees to be overestimated in the model results compared to results from palynological studies, which show that levees were the first parts in the river area to be deforested; often these areas were already deforested in the ERP (Teunissen, 1990; Kooistra, 1996; Kalis et al., 2008; Van Dinter et al., 2017). This is supported by archaeological records that show a shift in the origin of the used wood to wetter localities (Kooistra, 1996). It should be noted that it would probably only slightly influence present modelling results in terms of carrying capacity for arable land, pasture and meadow since it would mean that more suitable land is available. However, since timber is the primary building material in the Netherlands during the first millennium and often was used as a source for fuel, the model could be expanded to also include woodland as a fourth type of land use. This class can additionally be subdivided into dry forest and a wet forest (alder carr), which would have been located on the levees and in the floodbasins respectively.

\subsection{Palaeodemography}

Only settlements dating to specific ABR subperiods such as the ERP, MPR or LRP were included in the palaeodemographic reconstructions (Table 2; Section 4.1). Settlements dating to overarching ABR periods (Table 2) were excluded from the analyses since these do not provide high-resolution chronological data, and since their documentation often reflects inconsistencies in data administration. The reconstructed rural population numbers therefore might be a conservative estimate. However, the reliability of the presented results is supported by previous population estimates for the civitas Batavorum during the MRP (a region largely corresponding to our study area) by Vossen (2003) and by Willems et al. (2005), which derive between a minimum of 50,000 and an absolute maximum of 120,000 inhabitants. Nonetheless, the current demographic reconstructions might benefit from a more detailed analysis of settlement data per ABR (sub)period. Generally, the Roman period provides the highest chronological resolution in settlement data. This is mainly due to: (1) the general recognisability of Roman material culture in our study area, facilitating well-developed typologies and precise dating; and (2) this recognisable Roman-period division being built up out of relatively short time intervals. However, since our analyses cover a relatively large study area and long time period (over 1000 years), the least accurately dated sites constitute the bottleneck. A recent study by Verhagen et al. (2016b) presents a potentially promising detailed and statistical approach for increasing the chronological resolution of settlements in parts of the Rhine-Meuse delta. Such, or other, approaches might increase the chronological resolution of the dataset and also might help to determine the added value of including merely ABR-period dated settlements in palaeodemographic reconstructions.

Low-level urbanisation appears to have been of limited influence on total population numbers (rural and military numbers) during the Roman and early-medieval periods (Table 7). Increases of rural population numbers and large settlements occurred synchronously during the whole of the first millennium and there are no signs of large settlements extracting people from the countryside. During the MRP, only $11.1 \%$ of the total population lived in large settlements (Section 5.1; Fig. 8; 
Table 7). Additionally, with the exception of the Roman town at Nijmegen (Ulpia Noviomagus Batavorum), none of the larger settlements were officially designated as Roman towns (Municipia) and most were characterised by a few urban features only (e.g. monumental buildings, stone works). If we take this into account and only include the Municipia in the calculations, the percentage of people living in an urbanised context drops even further to $5.9 \%$. This low percentage is in line with urbanisation levels during the EMPB and EPMD. A major 'urbanised' exception is the EMPC, when $26.5 \%$ of the total population lived in large settlements (of which $86.8 \%$ inhabited the emporium of Dorestad; Table 5). However, if we assume that these extremely high percentages may reflect an overestimation by Van Es \& Verwers (2015) of the number of people simultaneously living in Dorestad, and recalculate the urbanisation percentage using older demographic estimations for Dorestad (i.e. c. 2500-4000 inhabitants; Van Es, 1990), the results still imply that $10.4 \%$ of the total population at this time lived in an urbanised context. This is almost twice as much as urban population numbers during the remaining subperiods of the Early Middle Ages. It should be noted that the effects of these urbanised regions on rural settlements probably differed per ABR subperiod and deserve further investigation. Nonetheless, even though our estimates of rural population numbers most likely are conservative, the effects of urbanisation (the large settlements only) during the first millennium appear to have been limited in terms of food production capacity.

Military presence fluctuated throughout the Roman period (Fig. 8; Table 7). During the transition from ERP to MRP the relative contribution of Roman military numbers to the total population was highest, reaching $24.9 \%$. During the heyday of Roman occupation, the MRP, the relative contribution of the Roman military was lowest, which is best explained by the strong increase of rural population numbers and by the political stability during this period. Although total Roman military numbers decreased during the LRP, the relative contribution of military presence in the total population rose to $14.0 \%$, mainly due to synchronous rural population decline.

Population numbers for the EMPD are difficult to calculate because of changing settlement types and instability caused by Viking raids. During the largest part of the Early Middle Ages, settlements contained an average of three houses. However, during the EMPD, settlements generally became larger, more fixed in space and more nucleated, and contained an average of five houses (e.g. Hamerow, 2002; Van der Velde, 2011; Van Beek et al., 2015; Table 3). Additionally, the number of individual settlements appears to have decreased. It has been suggested that because of these changes in settlement size, the total number of archaeologically traceable settlement sites dating from this period decreased significantly (Van Beek et al., 2015). However, this reduction in settlement numbers has also been explained by social unrest caused by increasingly frequent Viking raids (Henderikx, 1986). Additionally, it is highly likely that the EMPD is underrepresented in the archaeological datasets because until recently material from this period was hard to identify (Bartels et al., 1997). A more detailed analysis of settlement development during the transition period from the Early to High Middle Ages is needed to increase our understanding of EMPD palaeodemographics.

A main assumption of this study is that around $50 \%$ of Roman and early-medieval rural settlements in the study area are undiscovered (Section 4.1). However, the archaeological visibility of settlements varies per period and region, mainly due to period-specific differences in the manner in which these settlements manifest themselves in the archaeological record. The layout, recognisability, quantity and density of archaeological finds and features are crucial for the chronological interpretation of settlements. Consequently, these differences directly influence the archaeological visibility of settlements (Groenewoudt, 1994; Groenewoudt \& Smit, 2017). By further studying differences in material manifestations through time, visibility parameters can be determined for each ABR subperiod, enhancing the accuracy of past-population estimates, land-use simulations and settlement-location predictions (Hey \& Lacey, 2001; Tol et al., 2004; Rensink et al., 2017).

\subsection{Methodological considerations}

This study is a first exploration of evidence-based modelling of first-millennium population development and of using these quantitative demographic data to test archaeological hypotheses about past land use. By using high-resolution (bio)archaeological data we were able to reconstruct past population numbers and to calculate their corresponding impact on land use and the limits of the natural landscape in the RhineMeuse delta. The presented calculations and simulations are primarily based on general high-resolution estimates of food consumption during the Roman period by Kooistra et al. (2013) and Van Dinter et al. (2014). The PLUS modelling framework however is designed to incorporate, and to base calculations on, a multitude of cultural variables (De Kleijn et al., in press). The model could therefore be expanded to include, among others, more detailed (quantified) data representing socio-cultural variables such as property rights, organisation structures, political boundaries, and technological innovations. The same holds true for more detailed land-use and natural-landscape variables such as crop changes, crop rotations and the impact of flooding. Adding such high-resolution data surely will further enhance the accuracy of the modelling results.

Palaeodemographic and land-use dynamics occurred on a variety of scales, ranging from local self-sufficiency to more largescale patterns of long-distance transport. Van Lanen \& Pierik (2017) already concluded that these spatial-social manifestations are part of a larger system, which they termed 'connectivity patterns'. Researching phenomena such as palaeodemographics and land use requires methods and techniques 
equally reflecting this multi-scale variability. For example, palaeodemographic research can encompass studying past DNA and isotope data, both of which are very useful for reconstructing local-population variables such as diet, disease, mortality and mobility. However, these data currently still are restricted to mainly local overviews and lack large-scale data coverage. Consequently, at present they are less suited for large-scale population reconstructions. The challenge for palaeodemographic modelling in the near future is to bridge the gap between these scale differences. The new PLUS modelling framework has proven to be very promising in this respect, since it facilitates the combination, extrapolation and interpolation of data on multiple scale levels.

Although in the study area low-level urbanisation appears to have been of limited influence on population development (Section 6.2; Fig. 8; Table 7), further research into the exact influence of specific demographic and urbanisation processes, such as the percentage of people moving from the countryside to urban centres, average mortality, diseases, and fertility, might improve our understanding of past-population development. Verhagen et al. (2016a) already propagated the use of agent-based modelling ( $A B M)$ incorporating such processes for past-population reconstructions (Section 2). However, although ABM shows great promise in reconstructing such specific palaeodemographic processes, the accuracy of its results largely depend on the amount of available data. Therefore at present this approach is less suited for large-scale, evidencebased population reconstructions. To overcome this challenge, when reconstructing palaeodemography we propose the use of a combination of different (simulation-)modelling techniques facilitating a multi-proxy and multidisciplinary approach which incorporates a wide range of socio-cultural variables such as we have explored in this study.

\subsection{Outlook}

The PLUS simulation modelling applied in this study shows great promise regarding the integration of cultural and natural variables. However, it would be interesting to subject the model to a more extreme stress test in order to determine the current frameworks' computational limitations. By adding increasing numbers of cultural and/or natural variables into the calculations, the models' limits can be determined. In addition, the presented PLUS was developed for specific hypotheses-testing purposes in the Rhine-Meuse delta. It would be interesting to further test its applicability on other study regions, time intervals and landscape settings. The current PLUS proves itself very useful for at least delta regions and could easily be adapted for other similar regions in the world; however, applicability of this simulation framework should also be possible for nondelta regions both inside and outside the Netherlands. Furthermore, it would be interesting to adapt the PLUS to not only have a hypothesis-testing function, but also to investigate the reconstructive potential of this modelling framework. This can be achieved by further testing the models' outcomes with highresolution archaeological reconstructions. This, however, would require either larger amounts of high-resolution archaeological data, or working on much smaller spatial scales.

An important next step is to explore and validate our results by comparison with: (1) potential vegetation overviews which are based on the link between geomorphological units and vegetation preferences (Section 4.2); and (2) highly detailed vegetation reconstructions in line with Van Beek et al. (2015). Most vegetation reconstruction models and methods focus on the reconstruction of forest cover; since our approach did not include forest comparisons, vegetation reconstructions of this type are at the moment not possible. Additionally, it could prove most interesting to further analyse the impact of population trends and land-use changes on the natural-landscape development and identify relevant feedback mechanisms. Such analyses might provide more insight into how, for example, certain landscape dynamics trigger specific land-use systems or how regional water systems or avulsion processes influence first-millennium water management policies (e.g. the construction of dikes, culverts or sluices). Therefore, combining more high-resolution archaeological, palynological and geomorphological data in the future certainly will improve the resolution of the suitability map (underlying the present land-use model) and equally its reconstructive potential.

The current study shows that population-size fluctuations directly influenced past land use, but also vice versa. Van Lanen (2017) and Van Lanen \& Pierik (2017) have already addressed the multi-scale complexity of connectivity patterns, which clearly contain factors such as land use and palaeodemography. By using simulation modelling such as the PLUS it has proved possible to (partly) quantify and integrate traditionally qualitative data such as population trends with corresponding impact on the natural landscape. In turn this allows for (1) more detailed and objectified tests of traditional hypotheses and (2) the further unravelling of the relative contribution of individual CPFs within specific cultural developments. Future research into the interaction between these CPFs and the added value of simulation modelling such as the PLUS framework in unravelling these complex interrelationships should show the full potential of the exploration presented in this paper.

\section{Conclusion}

In this study we reconstructed first-millennium palaeodemographics with a high temporal resolution, using an evidencebased approach. By integrating high-resolution archaeological and historical data, we were able to reconstruct Roman and early-medieval habitation on an ABR-subperiod level for the whole of the fluvial-dominated part of the Rhine-Meuse delta. The presented modelling approach has proven to be highly 
promising for demographic reconstructions, since: (1) the modelling outcomes correspond with other (single-period) population reconstructions (Section 6.2); and (2) the results are based on a quantitative and integrated approach using sizable archaeological datasets.

Through the presented palaeodemographic modelling we were able to quantify past population numbers and, as a result, determine the impact of changing population numbers on past land use and reconstruct the potential limits of the natural landscape. The results demonstrate that the adapted PLUS is very useful for testing the feasibility of general archaeological hypotheses regarding past palaeodemographics and humanlandscape interactions. Despite major population-size fluctuations during the first millennium $\mathrm{AD}$, the impact of population dynamics never exceeded the limitations of the natural landscape in the study area. A significant finding is that the impact of Roman military population numbers on the landscape in this area appears to have been limited and that all food during this period could have been supplied from local sources. The same conclusion was reached for Dorestad during the Early Middle Ages. Although the impact of imports in both SGs should not be underestimated, these were never a crucial factor since the natural landscape was never a limiting factor. In addition, the multi-scenario approach of the PLUS model is crucial for reconstructing bandwidths of cultural-landscape change, allowing the identification of possible tipping points when the impact on the landscape became too severe (Section 6.1).

The PLUS modelling framework facilitates a multidisciplinary approach allowing us to combine demographic and land-use reconstructions. Such an integrated approach is essential since palaeodemographic and past land-use dynamics occurred on multiple scales (Section 6.3). The results of the presented PLUS show the high capacity of this model to integrate cultural and natural variables, which is essential for reconstructing spatiotemporal frameworks of past cultural-landscape changes, such as varying population densities on the natural landscape and changing land-use systems.

\section{Acknowledgements}

This study is part of the research programme "The Dark Age of the Lowlands in an interdisciplinary light: people, landscape and climate in the Netherlands between AD 300 and 1000' (www.darkagesproject.com) funded by the Netherlands Organisation for Scientific Research (NW0, section Humanities; 20122019: 360-60-110). The development of the PLUS received funding from the European Union's Seventh Framework Programme for research, technological development and demonstration under grant agreement nr. 603447 (FP7, Collaborative Project: HERCULES http://www.hercules-landscapes.eu/). The authors would like to thank Prof. Dr E. Jansma (Cultural Heritage Agency of the Netherlands and Utrecht University), Prof. Dr T. Spek (University of Groningen) and Dr B.J. Groenewoudt (Cultural
Heritage Agency of the Netherlands) for their comments on earlier drafts of the paper. Special thanks go to Drs T. de Groot Cultural Heritage Agency of the Netherlands, Dr S. Heeren (Vrije Universiteit), Drs J. van Doesburg (Cultural Heritage Agency of the Netherlands), Dr H. van Enckevort (municipality of Nijmegen) and Drs C. van Rooijen (Cultural Heritage Agency of the Netherlands) for their invaluable help with the demographic reconstructions for the Roman and early-medieval periods and to Dr Eric Koomen (Vrije Universiteit) and Frank Beijaard, MA (Vrije Universiteit) for the development of the PLUS.

\section{Supplementary material}

To view supplementary material for this article, please visit https://doi.org/10.1017/njg.2018.3

\section{References}

Alföldi, A., 1967. Studien zur Geschichte der Weltkrise des 3. Jahrhunderts nach Christus. Wissenschaftliche Buchgesellschaft (Darmstadt).

Arnoldussen, S., 2008. A living landscape: Bronze Age settlements in the Dutch river area (c. 2000-800 BC). PhD Thesis. Rijksuniversiteit Groningen (Groningen).

Bartels, M., Oudhof, J.W. \& Dijkstra, J., 1997. Duisburgse waar uit Ottoons Tiel. Een keramisch gidsfossiel voor de tiende eeuw? Westerheem 46(3): 2-15.

Bechert, T. \& Willems, W.J.H., 1995. De Romeinse rijksgrens tussen Moezel en Noordzeekust. Matrijs (Utrecht).

Berendsen, H.J.A. \& Stouthamer, E., 2000. Late Weichselian and Holocene palaeogeography of the Rhine-Meuse delta, the Netherlands. Palaeogeography, Palaeoclimatology, Palaeoecology 161: 311-335.

Berendsen, H.J.A. \& Volleberg, K.P., 2007. New prospects in geomorphological and geological mapping of the Rhine-Meuse Delta - application of detailed digital elevation maps based on laser altimetry. Netherlands Journal of Geosciences / Geologie en Mijnbouw 86: 15-22.

Bloemers, J.H.F., 1978. Rijswijk (ZH), 'De Bult'. Eine Siedlung der Cananefaten. PhD Thesis. University of Amsterdam (Amsterdam). Nederlandse Oudheden 8 (Amersfoort).

Blom, E. \& Vos, W.K., 2007. Woerden-Hoochwoert. De opgravingen 2002-2004 in het Romeinse castellum Laurium, de vicus en van het schip de 'Woerden 7 '. ADC rapport 910: 72-88.

Brulet, $R$., 2017. The Roman army and military defence in Northern Gaul and the Germanic provinces during the Late Empire. In: Roymans, N.G.A.M., Heeren, S. \& De Clercq, W. (eds): Social dynamics in the northwest frontiers of the late Roman Empire. Amsterdam University Press (Amsterdam): 39-56.

Brunsting, H., 1937. Het grafveld onder Hees bij Nijmegen. Een bijdrage tot de kennis van Ulpia Noviomagus. PhD Thesis. University of Amsterdam (Amsterdam University Press).

Bult, E.J., 1983. Midden-Delfland, een archeologische kartering, inventarisatie, waardering en bewoningsgeschiedenis. Nederlandse Archeologische Rapporten (NAR) 2 (Amersfoort).

Chamberlain, A.T., 2006. Demography in archaeology. Cambridge University Press (Cambridge). 
Cheyette, F.L., 2008. The disappearance of the ancient landscape and the climatic anomaly of the early Middle Ages: a question to be pursued. Early Medieval Europe 16(2): 127-165.

Cohen, K.M., 2005. 3D geostatistical interpolation and geological interpretation of paleo-groundwater rise in the Holocene coastal prism in the Netherlands river deltas - concepts, models and examples. SEPM Special Publication 83: 341-364.

Cohen, K.M., Stouthamer, E., Pierik, H.J. \& Geurts, A.H., 2012. Digitaal Basisbestand Paleogeografie van de Rijn-Maas Delta / Rhine-Meuse Delta Studies' Digital Basemap for Delta Evolution and Palaeogeography. Department of Physical Geography, Utrecht University (digital dataset). http://persistent-identifier. nl/?identifier=urn:nbn:nl:ui:13-nqin-zl

Cunliffe, B., 2004. Facing the ocean. The Atlantic and its peoples. Oxford University Press (0xford).

De Bakker, H. \& Schelling, J., 1989. Systeem van bodemclassificatie voor Nederland. De hogere niveaus, 2e gewijzigde druk. PUDOC (Wageningen).

Deeben, J.H.C., Groenewoudt, B.J., Hallewas, D.P., Van Rooijen, C.A.M. \& Zoetbrood, P.A.M., 2006. In search of the archaeological resource. Berichten van de Rijksdienst voor Oudheidkundig Bodemonderzoek (BROB) 46: 113-126.

De Kleijn, M.T.M., Beijaard, F., Koomen, E. \& Van Lanen, R.J., in press. Simulating past land-use patterns; the impact of the Romans on the Lower-Rhine delta in the first century AD. Journal of Archaeological Science: Reports.

De Moor, T., 2016. Dare to dig! More history is needed to take historical demography a few steps further... In: Matthijs, K., Hin, S., Kok, J. \& Matsuo, H. (eds): The future of historical demography: upside down and inside out. Acco (Leuven/The Hague): 16-18.

Den Braven, J.A., 2014. Karolingisch Nijmegen: de palts en zijn omgeving. Jaarboek Numaga 61: 20-39.

De Vries, F., de Groot, W.J.M., Hoogerland, T. \& Denneboom, J., 2003. De bodemkaart van Nederland digitaal;. Toelichting bij inhoud, actualiteit en methodiek en korte beschrijving van additionele informatie. Alterra-rapport 811 (Wageningen, Alterra Research Instituut voor de Groene Ruimte).

Dijkstra, M., 2011. Rondom de mondingen van Rijn \& Maas. Landschap en bewoning tussen de $3^{\mathrm{e}}$ en $9^{\mathrm{e}}$ eeuw in Zuid-Holland, in het bijzonder de Oude Rijnstreek. PhD Thesis. University of Amsterdam (Amsterdam).

Driessen, $\boldsymbol{M}$. , 2007. Bouwen om te blijven: de topografie, bewoningscontinuïteit en monumentaliteit van Romeins Nijmegen. PhD Thesis. University of Amsterdam (Amersfoort).

Goodchild, H. \& Witcher, R., 2010. Modelling the agricultural landscapes of Republican Italy. In: Carlsen, J. \& Lo Cascio, E. (eds): Agricoltura e Scambi nell'Italia tardo repubblicana. Edipuglia (Bari): 187-220.

Groenewoudt, B.J., 1994. Prospectie, waardering en selectie van archeologische vindplaatsen: een beleidsgerichte verkenning van middelen en mogelijkheden. PhD Thesis. University of Amsterdam (Amsterdam). Nederlandse Archeologische Rapporten (NAR) 17 (Amersfoort).

Groenewoudt, B.J., Eerden, M.C., De Groot, T. \& Theunissen, E.M., 2017. Answers to questions: the new National Archaeological Research Agenda of the Netherlands. In: Lauwerier, R.C.G.M., Eerden, M.C., Groenewoudt, B.J., Lascaris, M.A., Rensink, E., Smit, B.I., Speleers, B.P. \& Van Doesburg, J. (eds): Knowledge for informed choices. Tools for a more effective and efficient selection of valuable archaeology in the Netherlands. Nederlandse Archeologische Rapporten (NAR) 55: 179-194.
Groenewoudt, B.J. \& Smit, B.I., 2017. Four-period system of archaeology. In: Lauwerier, R.C.G.M., Eerden, M.C., Groenewoudt, B.J., Lascaris, M.A., Rensink, E., Smit, B.I., Speleers, B.P. \& Van Doesburg, J. (eds): Knowledge for informed choices. Tools for a more effective and efficient selection of valuable archaeology in the Netherlands. Nederlandse Archeologische Rapporten (NAR) 55: 25-31.

Groenman-Van Waateringe, $W_{.}, 1983$. The disastrous effect of the Roman occupation. In: Brandt, R. \& Slofstra, J. (eds): Roman and native in the Low Countries. BAR International Series 184: 147-157.

Hamerow, H.F., 2002. Early medieval settlements. The archaeology of rural communities in northwest Europe 400-900. 0xford University Press (0xford).

Hanel, N., 2007. Military camps, Canabae, and Vici. The archaeological evidence. In: Erdkamp, P. (ed.): A companion to the Roman Army. Blackwell Publishing (Malden, MA/0xford /Carlton): 395-416.

Harmsen, C., Den Braven, J.A. \& Hendriks, J., 2012. Archeologisch onderzoek in de Lentse Schoolstraat in Nijmegen-Lent. Nederzettingssporen uit de Vroege en Volle Middeleeuwen. Archeologische Berichten Nijmegen - Rapport 33 (Nijmegen).

Hassan, F.A., 1981. Demographic archaeology. Academic Press (New York).

Hazenberg, T., 2000. Leiden-Roomburg 1995-1997: Archeologisch onderzoek naar het kanaal van Corbulo en de vicus van het castellum Matilo. Rapportage Archeologische Monumentenzorg (RAM) 77 (Amersfoort).

Heeren, S., 2009. Romanisering van rurale gemeenschappen in de civitas Batavorum. De casus Tiel-Passewaaij. PhD Thesis. Vrije Universiteit Amsterdam (Amsterdam).

Heeren, S., 2015. The depopulation of the Lower Rhine region in the 3rd century. An archaeological perspective. In: Roymans, N., Derks, T. \& Hiddink, H. (eds): The Roman villa of Hoogeloon and the archaeology of the periphery. Amsterdam Archaeological Studies 22 (Amsterdam): 269292.

Henderikx, P.A., 1983. De beneden-delta van de Rijn en Maas. Landschap en bewoning van de Romeinse tijd tot ca. 1000. PhD Thesis. University of Amsterdam (Amsterdam).

Henderikx, P.A., 1986. The lower delta of the Rhine and the Maas: landscape and habitation from the Roman period to ca.1000. Berichten van de Rijksdienst voor Oudheidkundig Bodemonderzoek (BROB) 36: 447-599.

Hendriks, J., Den Braven, J.A., Van Enckevort, H. \& Thijssen, J., 2014. Een noordelijk steunpunt. Vroegmiddeleeuws Nijmegen vanuit archeologisch perspectief. In: Peterse, H., Verhoeven, D. \& Camps, R. (eds): Het Valkhof. 2000 jaar geschiedenis (Nijmegen): 43-69.

Hey, G. \& Lacey, M., 2001. Evaluation of archaeological decision-making processes and sampling strategies. Kent County Council (Maidstone)/0xford Archaeological Unit (0xford).

Hiddink, H.A., 1991. Rural centres in the Roman settlement system of Northern Gallia Belgica and Germania Inferior. In: Roymans, N.G.A.M. \& Theuws, F. (eds): Images of the past. Studies on ancient societies in northwestern Europe. Studies in Pre- en Protohistorie 7: 201-234.

Hilferink, M. \& Rietveld, P., 1999. Land Use Scanner: an integrated GIS-based model for long term projections of land use in urban and rural areas. Journal of Geographical Systems 1(2): 155-177.

Jansma, E., Gouw-Bouman, M., Van Lanen, R.J., Pierik, H.J., Cohen, K.M., Groenewoudt, B., Hoek, W.Z., Stouthamer, E. \& Middelkoop, H., 2014. The 
Dark Age of the Lowlands in an interdisciplinary light: people, landscape and climate in The Netherlands between AD 300 and 1000. European Journal of Post-Classical Archaeology 4: 473-478.

Kalis, A.J., Karg, S., Meurers-Balke, J. \& Teunissen-van Oorschot, H., 2008. Mensch und Vegetation am Unteren Niederrhein während der Eisen- und Römerzeit. In: Traiana, Colonia Ulpia. Xanten und sein Umland in römischer Zeit. Sonderband Xantener Berichte / Geschichte der Stadt Xanten (Mainz): 31-48.

Kooistra, L.I., 1996. Borderland farming. Possibilities and limitations of farming in the Roman Period and Early Middle Ages between the Rhine and Meuse. Van Gorcum (Assen).

Kooistra, L.I., Van Dinter, M., Dütting, M.K., Van Rijn, P. \& Cavallo, C., 2013. Could the local population of the Lower Rhine delta supply the Roman Army? Part 1: The archaeological and historical framework. Journal of Archaeology in the Low Countries 4(2): 5-23.

Koomen, E. \& Borsboom-Van Beurden, J., 2011. Land-use modelling in planning practice. GeoJournal Library 101 (Dordrecht).

Koster, K., Stafleu, J. \& Cohen, K.M., 2016. Generic 3D interpolation of Holocene base-level rise and provision of accommodation space, developed for the Netherlands coastal plain and infilled palaeovalleys. Basin Research 29(6): 775-797.

Kuys, J. \& Bots, H., 2005. Nijmegen, Geschiedenis van de oudste stad van Nederland, Middeleeuwen en nieuwe tijd. Inmerc (Wormer).

Lake, M., 2014. Trends in archaeological simulation. Journal of Archaeological Method and Theory 21: 258-287.

Louwe Kooijmans, L.P., 1974. The Rhine/Meuse Delta: four studies on its prehistoric occupation and Holocene geology. Analecta Praehistorica Leidensia 7 (Leiden).

Lower Germanic Limes World Heritage Database, 2010. Der Deutschen Limeskomission and the Cultural Heritage Agency of the Netherlands (RCE). Bödecker, S. \& Van Marrewijk, D., 2010. Auf dem Weg zum Welterbe? Internationale Tagung zum Niedergermanischen Limes, Nachrichtenblatt der Deutschen Limeskommission Vol. 4, Issue 1 (München).

McCormick, M., 2007. Origins of the European economy. Communications and commerce AD 300-900. Cambridge University Press (Cambridge).

Oudhof, J.W., Verhoeven, A.A.A. \& Schuuring, I., 2013. Tiel rond 1000: analyse van vier opgravingen in de Tielse binnenstad. Spa (Amsterdam).

Pierik, H.J., Cohen, K.M. \& Stouthamer, E., 2016. A new GIS approach for reconstructing and mapping dynamic late Holocene coastal plain palaeogeography. Geomorphology 210: 55-70.

Pierik, H.J., Stouthamer, E. \& Cohen, K.M., 2017. Natural levee evolution in the Rhine-Meuse delta during the first millennium CE. Geomorphology 295: 215234.

Pierik, H.J. \& Van Lanen, R.J., 2017. Roman and early-medieval occupation patterns in a delta landscape: the link between settlement elevation and landscape dynamics. Quaternary International. DOI: 10.1016/j.quaint.2017.03.010.

Ploegaert, P.H.J.I., 2006. Zwammerdam 'De Hooge Burch' en 'De Bruggen'. ADCrapport 540 (Amersfoort).

Polak, M., 2009. The Roman military presence in the Rhine Delta in the period c. AD 40-140. In: Morillo, A., Hanel, N. \& Martín, E. (eds): LIMES XX. Roman Frontier Studies 13 (Madrid): 945-953.

Renes, H., 2005. Historische atlas van de stad Utrecht. SUN (Amsterdam).
Rensink, E., De Kort, J.W., Van Doesburg, J., Theunissen, E.M. \& Bouwmeester, H.M.P., 2017. Prospection made-to-measure. A digital information system for prospection methods, In: Lauwerier, R.C.G.M., Eerden, M.C., Groenewoudt, B.J., Lascaris, M.A., Rensink, E., Smit, B.I., Speleers, B.P. \& Van Doesburg, J. (eds): Knowledge for informed choices. Tools for a more effective and efficient selection of valuable archaeology in the Netherlands. Nederlandse Archeologische Rapporten 55: 165-175.

Roorda, I.M. \& Wiemer, R., 1992. The ARCHIS Project: towards a new national archaeological record in the Netherlands. In: Larsen, C. (ed.): Sites and monuments: national archaeological records. The National Museum of Denmark (Copenhagen): 117-122.

Schiffer, M.B., 1976. Behavioral archaeology. Academic Press (New York).

Schiffer, M.B., 1987. Formation processes of the archaeological record. University of New Mexico Press (Albuquerque, NM).

Shennan, S., 1998. Population and demography. World Archaeology 3-2 (London).

Sommer, C.S., 1984. The military vici in Roman Britain. Aspects of their origins, their location and layout, administration, function and end. BAR International Series 129 (0xford).

Sommer, C.S., 1991. Life beyond the ditches: housing and planning of the military vici in Upper Germany and Raetia. In: Maxfield, V.A. \& Dobson, M.J. (eds): Roman frontier studies 1989, Proceedings of the XVth International Congress of Roman Frontier Studies (Exeter): 472-476.

Teunissen, D., 1990. Palynologisch onderzoek in het oostelijk rivierengebied: een overzicht. Mededelingen van de Afdeling Biogeologie van de Sectie Biologie van de Katholieke Universiteit van Nijmegen 16. Katholieke Universiteit van Nijmegen (Nijmegen).

Theuws, F.C.W.J., 1988. De archeologie van de periferie: studies naar de ontwikkeling van bewoning en samenleving in het Maas-Demer-Schelde gebied in de vroege middeleeuwen. PhD Thesis. University of Amsterdam (Amsterdam).

Tol, A.J., Verhagen, J.W.H.P., Borsboom, A. \& Verbruggen, M., 2004. Prospectief boren; een studie naar de betrouwbaarheid en toepasbaarheid van booronderzoek in de prospectiearcheologie. RAAP-rapport 1000 (Amsterdam).

Van Beek, R., 2009. Reliëf in Tijd en Ruimte. Interdisciplinair onderzoek naar bewoning en landschap van 0ost-Nederland tussen de vroege prehistorie en middeleeuwen. PhD Thesis. Wageningen University (Wageningen).

Van Beek, R., Gouw-Bouman, M.T.I.J. \& Bos, J.A.A., 2015. Mapping regional vegetation developments in Twente (the Netherlands) since the Late Glacial and evaluating contemporary settlement patterns. Netherlands Journal of Geosciences / Geologie en Mijnbouw 94: 229-255.

Van Daele, B., 2003. Het Romeinse leger. Davidsfonds (Leuven).

Van der Leeuw, S.E. \& McGlade, J., 1997. Time, process and structured transformation in archaeology. Routledge (London).

Van der Velde, H.M., 2011, Wonen in een grensgebied. PhD Thesis. Vrije Universiteit Amsterdam. Nederlandse Archeologische Rapporten (NAR) 40 (Amersfoort).

Van Dinter, M., 2013. The Roman Limes in the Netherlands: how a delta landscape determined the location of the military structures. Netherlands Journal of Geosciences / Geologie en Mijnbouw 92: 11-32.

Van Dinter, M., Kooistra, L.I., Dütting, M.K., Van Rijn, P. \& Cavallo, C., 2014. Could the local population of the Lower Rhine delta supply the Roman Army? Part 2: Modelling the carrying capacity using archaeological, palaeo-ecological 
and geomorphological data. Journal of Archaeology in the Low Countries 5: 5-50.

Van Dinter, M., Cohen, K.M., Hoek, W., Stouthamer, E., Jansma, E. \& Middelkoop, H., 2017. Late Holocene lowland fluvial archives and geoarchaeology: Utrecht's case study of Rhine river abandonment under Roman and Medieval settlement. Quaternary Science Reviews 166: 227-265.

Van Dinter, M., 2017. Living along the Limes: landscape and settlement in the Lower Rhine Delta during Roman and Early Medieval times. PhD Thesis. Utrecht University (Utrecht).

Van Doesburg, J., in prep. Torenhoge ambitie; ontginning, elitevorming en kastelenbouw in het Kromme Rijngebied in de middeleeuwen. PhD Thesis. Vrije Universiteit Amsterdam (Amsterdam).

Van Enckevort, H. \& Thijssen, J., 2002. Cuijk. Een regionaal centrum in de Romeinse tijd. Matrijs (Utrecht).

Van Es, W.A., 1981. De Romeinen in Nederland. Fibula-van Dishoeck (Bussum).

Van Es, W.A., 1990. Dorestad centred. In: Besteman, J.C., Bos, J.M. \& Heidinga, H.A. (eds): Medieval Archaeology in the Netherlands. Van Gorcum (Essen): 151-182.

Van Es, W.A. \& Hessing, W.A.M., 1994. Romeinen, Friezen en Franken in het hart van Nederland. Van Traiectum tot Dorestad 50 v. c. -900 n. C. Matrijs (Utrecht/Amersfoort).

Van Es, W.A. \& Verwers, W.J.H., 2010. Early Medieval settlements along the Rhine: precursors and contemporaries of Dorestad. Journal of Archaeology in the Low Countries 2(1): 5-39.

Van Es, W.A. \& Verwers, W.J.H., 2015. Excavations at Dorestad 4. The settlement area at the harbour. Nederlandse Oudheden 18 (Amersfoort).

Van Lanen, R.J., 2017. Changing ways: patterns of connectivity, habitation and persistence in North West European lowlands during the first millennium AD. PhD Thesis. Utrecht University: Utrecht Studies in Earth Sciences 131 (Utrecht).

Van Lanen, R.J. \& Pierik, H.J., 2017. Calculating connectivity patterns in delta landscapes: modelling Roman and early-medieval route networks and their stability in dynamic lowlands. Quaternary International. DOI: 10.1016/j.quaint.2017.03.009.

Van Rooijen, C., 2010. Utrecht in the early medieval period. An archaeological analysis of its topography and a discussion of the location of the Stathe vicus. Medieval and Modern Matters 1: 155-196.

Verhagen, J.W.H.P., Joyce, J.A. \& Groenhuijzen, M.R., 2016a. Modelling the dynamics of demography in the Dutch Roman Limes Zone. Landscape Archaeology Conference (LAC2014). Conference proceedings. DOI: 10.5463/lac.2014.62.

Verhagen, J.W.H.P., Vossen, I.M.J., Groenhuijzen, M.R. \& Joyce, J.A., 2016b. Now you see them, now you don't: defining and using a flexible chronology of sites for spatial analysis of Roman settlement in the Dutch river area. Journal of Archaeological Science: Reports 10: 309-321.

Verwers, W.J.H., 1998. North Brabant in Roman and Early Medieval times. Habitation history. PhD Thesis. Vrije Universiteit Amsterdam (Amersfoort).

Vos, P.C., 2015. Origin of the Dutch Coastal landscape; long term landscape evolution to the Netherlands during the Holocene, described and visualized in national regional and local palaeographical map series. PhD Thesis. Utrecht University (Utrecht).

Vos, W.K., 2009. Bataafs platteland. Het Romeinse nederzettingslandschap in het Nederlandse Kromme- Rijngebied. PhD Thesis. Vrije Universiteit Amsterdam. Nederlandse Archeologische Rapporten (NAR) 35 (Amersfoort).
Vos, W.K., Van der Linden, E. \& Voormolen, B., 2012. Rondom Romeinse Rijtjeshuizen Reconstructie van een woonwijk op grond van een vergeten opgraving in Valkenburg ( $\mathrm{ZH})$. Hazenberg Archeologische Series 2 (Leiden).

Vossen, I.M.J., 2003. The possibilities and limitations of demographic calculations in the Batavian area. In: Grünewald, Th. \& Seibel, S. (eds): Kontinuität und Diskontinuität. Germania inferior am Beginn und am Ende der römischen Herrschaft, Reallexikon der Germanischen Altertumskunde Ergänzungsband 35: 414-435.

Vossen, I.M.J. \& Groot, M., 2009. Barley and horses, surplus and demand in the Civitas Batavorum. In: Driessen, M., Heeren, S., Hendriks, J., Kemmers, F. \& Visser, R. (eds): TRAC 2008, Proceedings of the Eighteenth Annual Theoretical Roman Archaeology Conference (0xford): 85-100.

Waasdorp, J.A. \& Van Zoolingen, R.J., 2015. Den Haag Ockenburgh II. Een Romeinse militaire vicus vlak bij de kust. Haagse Oudheidkundige Publicaties 18 (Den Haag).

Weeda, E.J., Westra, R., Westra, C. \& Westra, T., 1985. Nederlandse oecologische flora, wilde planten en hun relaties. deel 1. IVN (Hilversum).

Weeda, E.J., Westra, R., Westra, C. \& Westra, T., 1987. Nederlandse oecologische flora, wilde planten en hun relaties. deel 2. IVN (Hilversum).

Weeda, E.J., Westra, R., Westra, C. \& Westra, T., 1988. Nederlandse oecologische flora, wilde planten en hun relaties. deel 3. IVN (Hilversum).

Weeda, E.J., Westra, R., Westra, C. \& Westra, T., 1991. Nederlandse oecologische flora, wilde planten en hun relaties. deel 4. IVN (Hilversum).

Weeda, E.J., Westra, R., Westra, C. \& Westra, T., 1994. Nederlandse oecologische flora, wilde planten en hun relaties. deel 5. IVN (Hilversum).

Weeda, E.J., Schaminée, J.H.J. \& Van Duuren, L., 2000. Atlas van Plantengemeenschappen in Nederland. deel 1: Wateren, moerassen en natte heiden. Knnv (Utrecht).

Weeda, E.J., Schaminée, J.H.J. \& Van Duuren, L., 2003. Atlas van Plantengemeenschappen in Nederland. deel 3: Kust en binnenlandse pioniermilieus. Knnv (Utrecht).

Weeda, E.J., Schaminée, J.H.J. \& Van Duuren, L., 2005. Atlas van Plantengemeenschappen in Nederland. deel 4: Bossen, struwelen en ruigten. Knnv (Utrecht).

Westhoff, V., Bakker, P.A., Van Leeuwen, C.G. \& Van der Voo, E.E., 1970a. Wilde Planten, flora en vegetatie in onze natuurgebieden. deel 1 , vereniging tot behoud van natuurmonumenten in Nederland (Deventer).

Westhoff, V., Bakker, P.A., Van Leeuwen, C.G. \& Van der Voo, E.E., 1970b. Wilde Planten, flora en vegetatie in onze natuurgebieden. deel 2. vereniging tot behoud van natuurmonumenten in Nederland (Deventer).

Westhoff, V., Bakker, P.A., Van Leeuwen, C.G. \& Van der Voo, E.E., 1970c. Wilde Planten, flora en vegetatie in onze natuurgebieden. deel 3. vereniging tot behoud van natuurmonumenten in Nederland (Deventer).

Whitley, T.G., Moore, G., Goel, G. \& Jackson, D., 2010. Beyond the marsh: settlement choice, perception and spatial decision-making on the Georgia Coastal Plain. In: Frischer, B., Crawford, J. \& Kollers, D. (eds): Making history interactive. Computer applications and quantitative methods in archaeology. Proceedings of the 37th Conference: 380-390.

Wiemer, R., 2002. Standardisation: the key to archaeological data quality. In: García Sanjuan, L. \& Wheatley, D.W. (eds): Mapping the future of the past, managing the spatial dimension of the 
European archaeological resource. Universidad de Sevilla (Sevilla): 103-108.

Willems, W.J.H., 1986. Romans and Batavians. A regional study in the Dutch Eastern River Area. PhD Thesis. University of Amsterdam (Amsterdam).

Willems, W.J.H. \& Van Enckevort, H., 2009. Ulpia Noviomagus Roman Nijmegen. The Batavian capital at the imperial frontier. Journal of Roman Archaeology supplementary series 73 (Portsmouth).

Willems, W.J.H., Enckevort, H.L.H., Haalebos, J.K. \& Thijssen, J., 2005. Nijmegen. Geschiedenis van de oudste stad van Nederland. Prehistorie en oudheid. Inmerc (Wormer).

\section{Websites}

Archaeological Information System of the Netherlands (ARCHIS): https:// archis.cultureelerfgoed.nl/\#/login (accessed on 22 April 2018)

Electronic Archiving System (EASY): https://easy.dans.knaw.nl (accessed on 22 April 2018)

Archaeological Basic Register (ABR): http://cultureelerfgoed.nl/sites/default/ files/downloads/dossiers/abr_website2.pdf (accessed on 22 April 2018)

National research agenda archaeology (NOaA 2.0) http://noaa.rce.rnatoolset. net/Viewer/\#/search (accessed: 22 April 2018) 